\title{
Phosphorus and E. coli in the Fanno and Bronson Creek Subbasins of the Tualatin River Basin, Oregon, During Summer Low-Flow Conditions, 1996
}

\section{U.S. GEOLOGICAL SURVEY \\ Water-Resources Investigations Report 00-4062}


Page Intentionally Blank 
Phosphorus and E. coli in the Fanno and Bronson Creek Subbasins of the Tualatin River Basin, Oregon, During Summer Low-Flow Conditions, 1996

By KATHLEEN A. McCARTHY

U.S. GEOLOGICAL SURVEY

Water-Resources Investigations Report 00-4062 


\section{U.S. DEPARTMENT OF THE INTERIOR BRUCE BABBITT, Secretary}

U.S. GEOLOGICAL SURVEY

Charles G. Groat, Director

The use of trade, product, or firm names in this publication is for descriptive purposes only and does not imply endorsement by the U.S. Government.

For additional information contact:

District Chief

U.S. Geological Survey

10615 S.E. Cherry Blossom Drive

Portland, OR 97216-3159

E-mail: info-or@usgs.gov

Internet: http://oregon.usgs.gov
Copies of this report can be purchased from:

U.S. Geological Survey

Branch of Information Services

Box 25286, Federal Center

Denver, CO 80225-0046 


\section{CONTENTS}

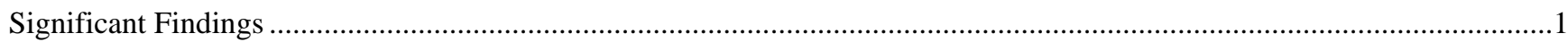

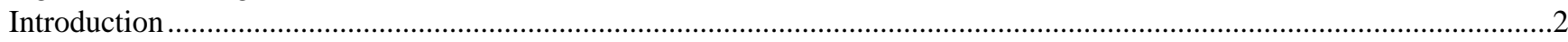

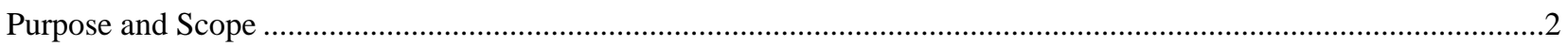

Acknowledgments

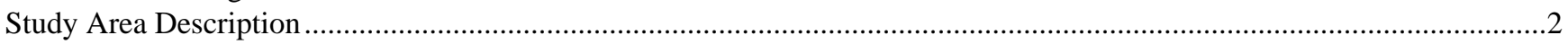

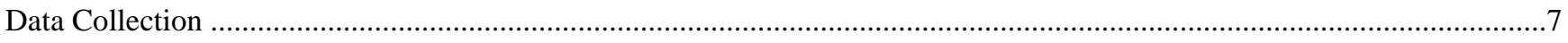

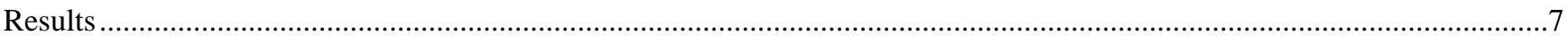

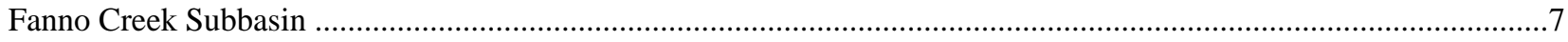

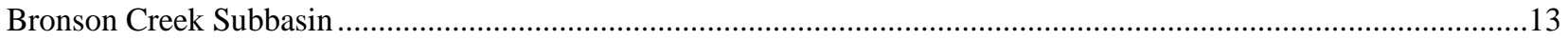

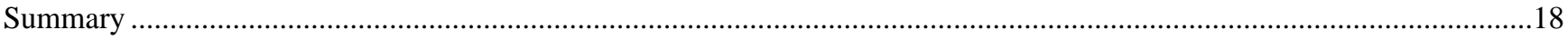

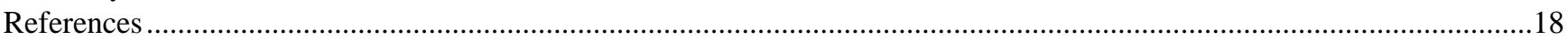

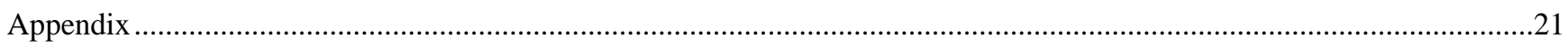

FIGURES

$1-2$. Maps showing:

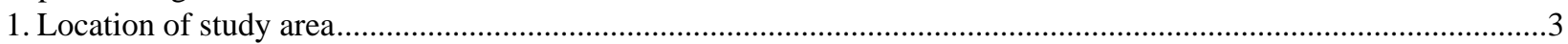

2. Location of Fanno and Bronson Creek subbasins and data-collection sites ...........................................................

$3-4$. Hydrographs showing:

3. Fanno Creek at 56th (station 14206900), water years 1991-97 …….................................................................

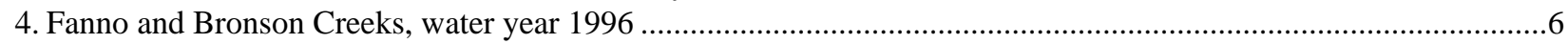

5-12. Graphs showing:

5. Total phosphorus in the Fanno Creek subbasin, September 1996 .....................................................................

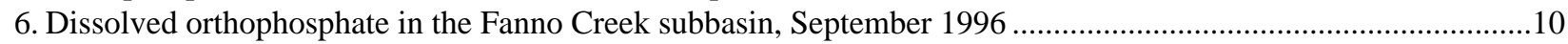

7. Ratio of dissolved orthophosphate to total phosphorus in the Fanno Creek subbasin, September 1996 ..................11

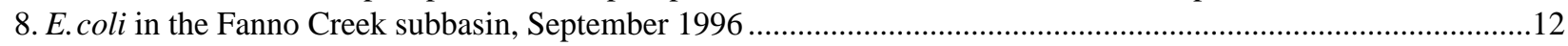

9. Total phosphorus in the Bronson Creek subbasin, September 1996 .................................................................14

10. Dissolved orthophosphate in the Bronson Creek subbasin, September 1996 ......................................................15

11. Ratio of dissolved orthophosphate to total phosphorus in the Bronson Creek subbasin, September 1996...............16

12. E. coli in the Bronson Creek subbasin, September 1996............................................................................... 17

\section{TABLES}

1. Ground-water phosphorus data from piezometers installed in Fanno Creek ……....................................................

A1. Discharge, phosphorus, nitrogen, and E.coli data collected in the Fanno Creek subbasin, September 10, 1996 ..........22

A2. Field, oxygen-demand, and solids data collected in the Fanno Creek subbasin, September 10, 1996 .........................24

A3. Major-ion data collected in the Fanno Creek subbasin, September 10, 1996 .........................................................26

A4. Discharge, phosphorus, nitrogen, and E. coli data collected in the Bronson Creek subbasin, September 24, 1996 .......29

A5. Field, oxygen-demand, and solids data collected in the Bronson Creek subbasin, September 24, 1996 ......................30

A6. Major-ion data collected in the Bronson Creek subbasin, September 24, 1996 ...........................................................31 
Page Intentionally Blank 


\title{
Phosphorus and E. coli in the Fanno and Bronson Creek Subbasins of the Tualatin River Basin, Oregon, During Summer Low-Flow Conditions, 1996
}

\author{
By Kathleen A. McCarthy
}

\section{SIGNIFICANT FINDINGS}

As part of an ongoing cooperative study between the Unified Sewerage Agency of Washington County, Oregon, and the U.S. Geological Survey, phosphorus and Escherichia coli (E. coli) concentrations were measured in the Fanno and Bronson Creek subbasins of the Tualatin River Basin during September 1996. Data were collected at 19 main-stem and 22 tributary sites in the Fanno Creek subbasin, and at 14 main-stem and 4 tributary sites in the Bronson Creek subbasin. These data provided the following information on summer base-flow conditions in the subbasins:

- Concentrations of total phosphorus at 70\% of the sites sampled in the Fanno Creek subbasin were between 0.1 and $0.2 \mathrm{mg} / \mathrm{L}$ (milligrams per liter), very near the estimated background level of $0.14 \mathrm{mg} / \mathrm{L}$ attributed to ground-water base flow. These data indicate that ground-water discharge could account for the phosphorus measured at most sites in this subbasin.

- Concentrations of phosphorus at all but one of the sites sampled in the Bronson Creek subbasin were also between 0.1 and $0.2 \mathrm{mg} / \mathrm{L}$, indicating that ground-water discharge could account for the phosphorus measured at most sites in this subbasin.

- A few sites in the Fanno Creek subbasin had phosphorus concentrations above background levels, indicating a source other than ground water. Some of these sites- Pendleton Creek and the tributary near Gemini, for example-were probably affected by the decomposition of avian waste materials and the release of phosphorus from bottom sediments in nearby ponds.

- Concentrations of E. coli-an indicator of fecal contamination and the potential presence of bacterial pathogens-exceeded the current single-sample criterion for recreational contact in freshwater (406 organisms/100 mL [organisms per 100 milliliters]) at $70 \%$ of the sites sampled in the Fanno Creek subbasin.

- Concentrations of $E$. coli in the Bronson Creek subbasin exceeded the single-sample criterion at one-third of the sites sampled.

- Most occurrences of elevated E. coli levels were probably due to sources such as domestic pet and wildlife waste, failing septic systems, or improperly managed hobby farms. The data did not indicate any large breaks in sewer lines or other large-scale sources of bacterial contamination to surface water in either subbasin during this low-flow period. 


\section{INTRODUCTION}

The Tualatin River drains a rapidly developing 712-square-mile basin in northwestern Oregon, just west of the Portland metropolitan area (fig. 1). The Unified Sewerage Agency (USA) of Washington County is charged with sanitary-sewer and stormwater management throughout most of the urban part of the basin (serving approximately 370,000 residents) and is in the process of developing management plans to address water-quality issues specific to individual subbasins.

In 1990, USA began a cooperative investigation with the U.S. Geological Survey (USGS) to assess a number of water-quality issues throughout the Tualatin River Basin related to the establishment of and compliance with Total Maximum Daily Loads developed for the basin pursuant to requirements of the Federal Clean Water Act. As part of this ongoing study, phosphorus and Escherichia coli (E. coli) concentrations characteristic of summer low-flow conditions in the Fanno and Bronson Creek subbasins were investigated during September 1996. Phosphorus is regulated in the basin as a result of nuisance algal blooms and historically high $\mathrm{pH}$ levels in the Tualatin River main stem, and understanding phosphorus contributions from tributaries is critical for effective management of main-stem concentrations. In addition, a number of stream segments within the Tualatin River Basin - including both Fanno and Bronson Creeksare on Oregon's 1998 303(d) list for water bacterial violations (http://waterquality.deq.state.or.us/wq 1303dlist/ 303dpage.htm, accessed October 20, 1999). E. coli is a common microorganism that inhabits the intestinal tracts of humans and other warm-blooded animals. The presence of $E$. coli in water is therefore an indicator of fecal contamination and signals the potential presence of bacterial pathogens. Understanding where elevated bacterial concentrations occur in the subbasins is necessary for development of effective, relevant mitigation plans.

\section{Purpose and Scope}

Data collected during the September 1996 sampling of the Fanno and Bronson Creek subbasins are presented in this report. Summer base-flow phosphorus and $E$. coli concentrations in the two subbasins and their potential impact on water-quality conditions in the Tualatin River main stem are discussed.

\section{Acknowledgments}

Special thanks are extended to the USA waterquality laboratory staff-especially Jan Wilson, Tom Auran, and Bill Byrne-Jan Miller of the USA, and the USGS sampling teams-Clyde Doyle, Howard Harrison, Matt Johnston, and Stewart Rounds.

\section{STUDY AREA DESCRIPTION}

The Tualatin River Basin is described in a number of reports published as part of the ongoing USA/USGS cooperative investigation of the basin (for example, Kelly, 1997; Risley, 1997; and Kelly et al., 1999). Characteristics of the Fanno and Bronson Creek subbasins relevant to this particular study are described briefly below.

Fanno Creek subbasin.-Fanno Creek drains a 32-square-mile area in the southeastern part of the Tualatin River Basin and flows directly into the mainstem Tualatin River at river mile 9.3 (figs. 1 and 2). Many tributaries flow into Fanno Creek along its 15-mile route, and some of them-such as Sylvan Creek, Summer Creek, and Ball Creek-contribute substantial discharges to the Fanno Creek main stem. The subbasin — encompassing parts of Portland, Beaverton, Tigard, and Durham-is classified as $100 \%$ urban and has been intensively developed for many years.

Bronson Creek subbasin.- - The Bronson Creek subbasin consists of approximately 5 square miles in the eastern part of the Tualatin River Basin (figs. 1 and 2). Bronson Creek flows into Beaverton Creek, which is a tributary of Rock Creek; Rock Creek flows into the Tualatin River at river mile 38.1. Bronson Creek has few tributaries, but several ponds-many artificially constructed-are present along the creek's flow path. The subbasin is only partially developed, but is currently undergoing rapid urbanization. 


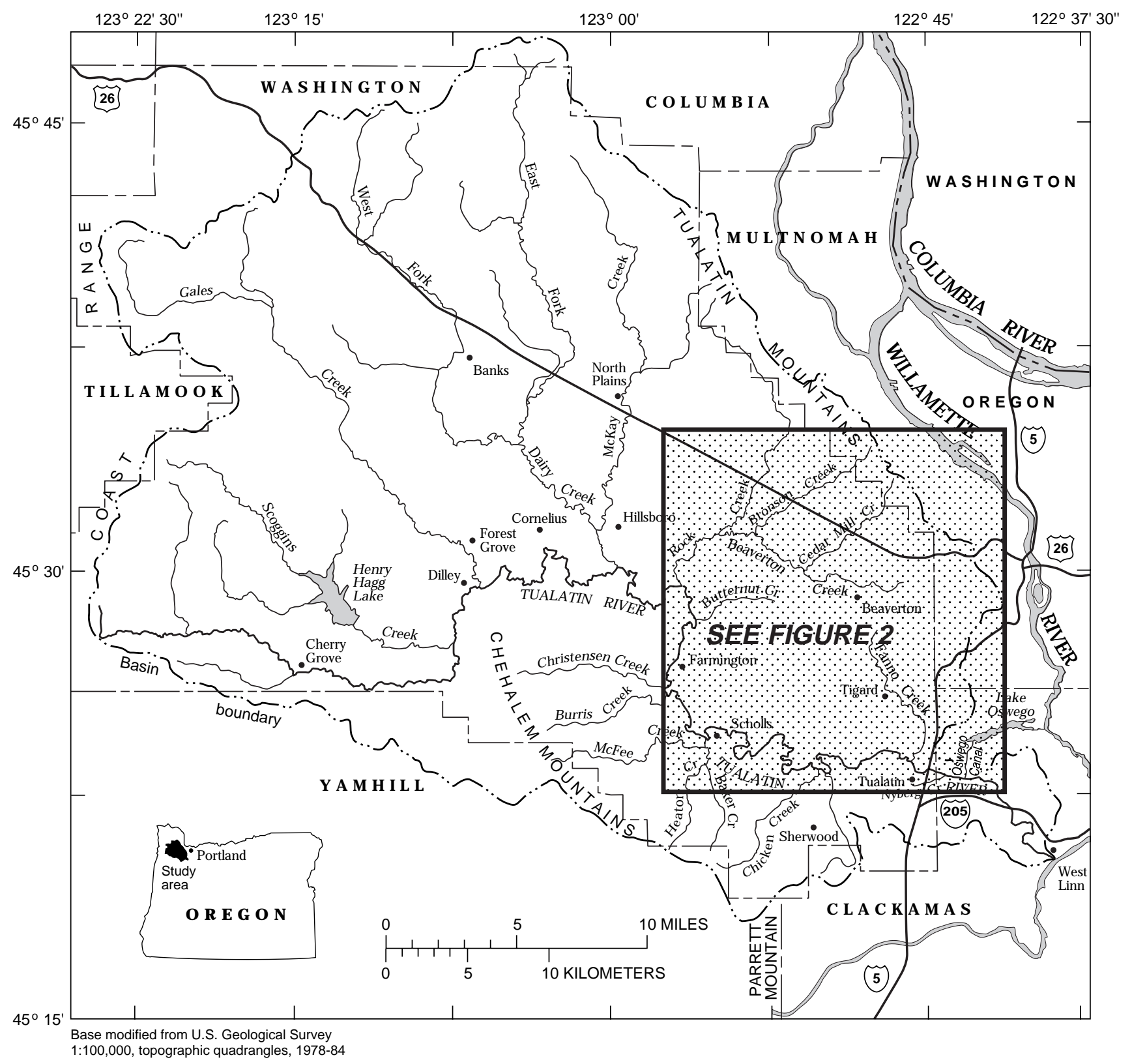

Figure 1. Location of study area.

Hydrology.-The annual discharge patterns in streams throughout the Tualatin River Basin are generally similar. The hydrograph of discharge in Fanno Creek during water years 1992-97 (fig. 3) shows that the period of lowest discharge for these streams typically occurs during the summer, when precipitation is relatively scarce. During this low-flow period, ground-water discharge is the predominant source of water to these streams.
Data for this study were collected during the late summer low-flow period (fig. 4).

Although a minor rainfall event occurred before the Bronson Creek sampling, flows had returned to prestorm levels 4 days prior to sampling.

Therefore, the data presented here should be representative of summer base-flow conditions in the Fanno and Bronson Creek subbasins. 


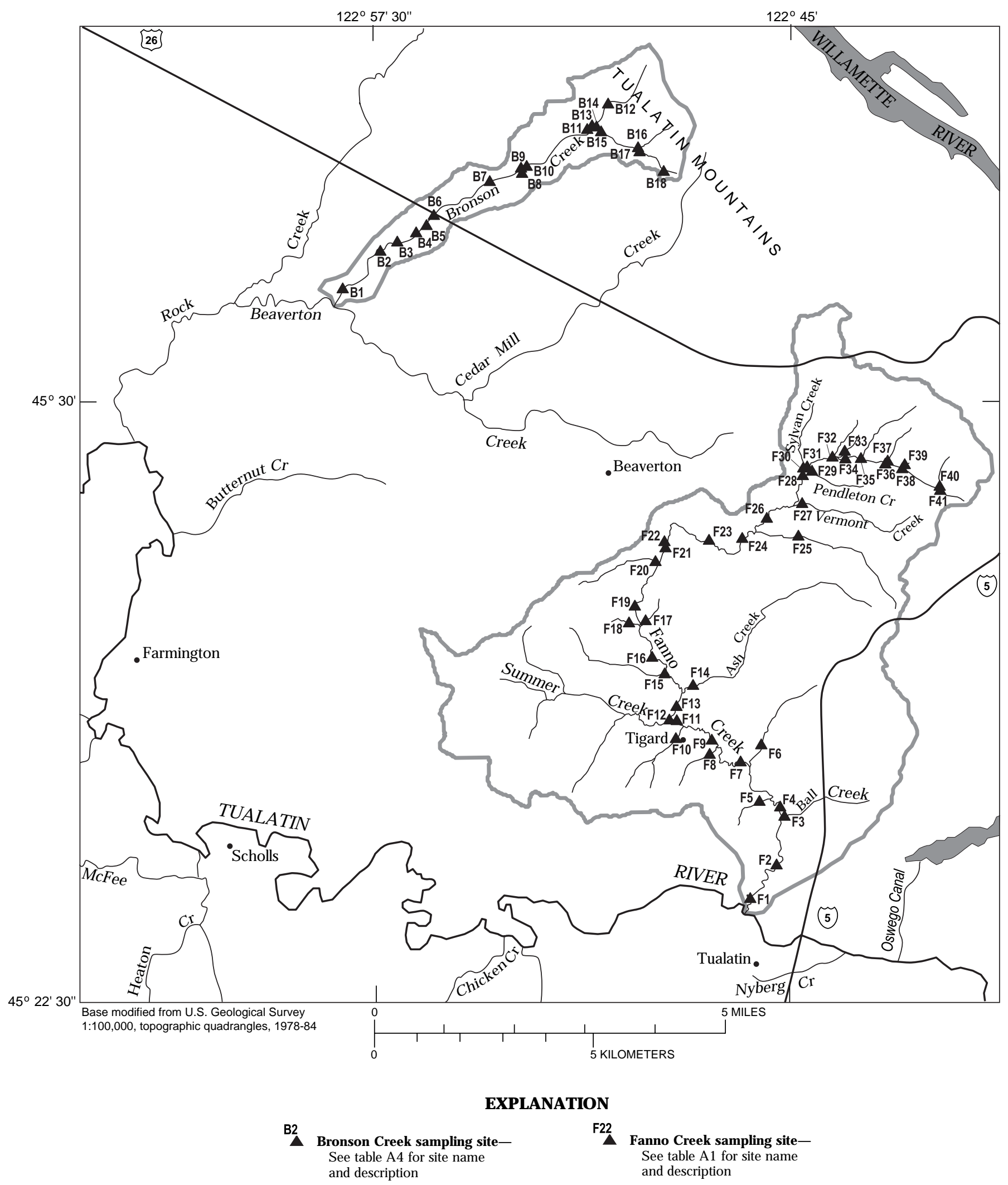

Figure 2. Location of Fanno and Bronson Creek subbasins and data-collection sites. 


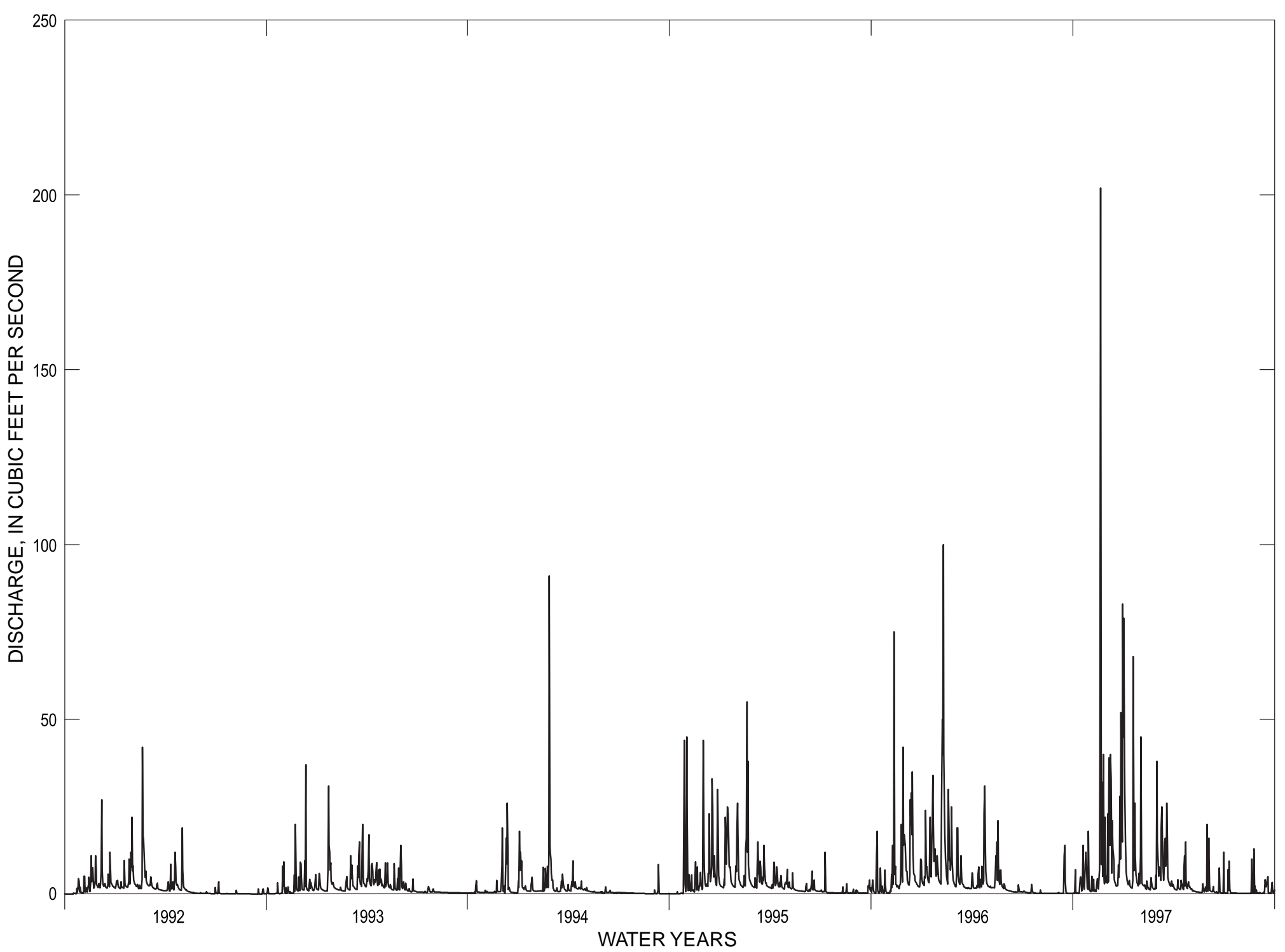

Figure 3. Fanno Creek at 56th (station 14206900), water years 1992-97. 


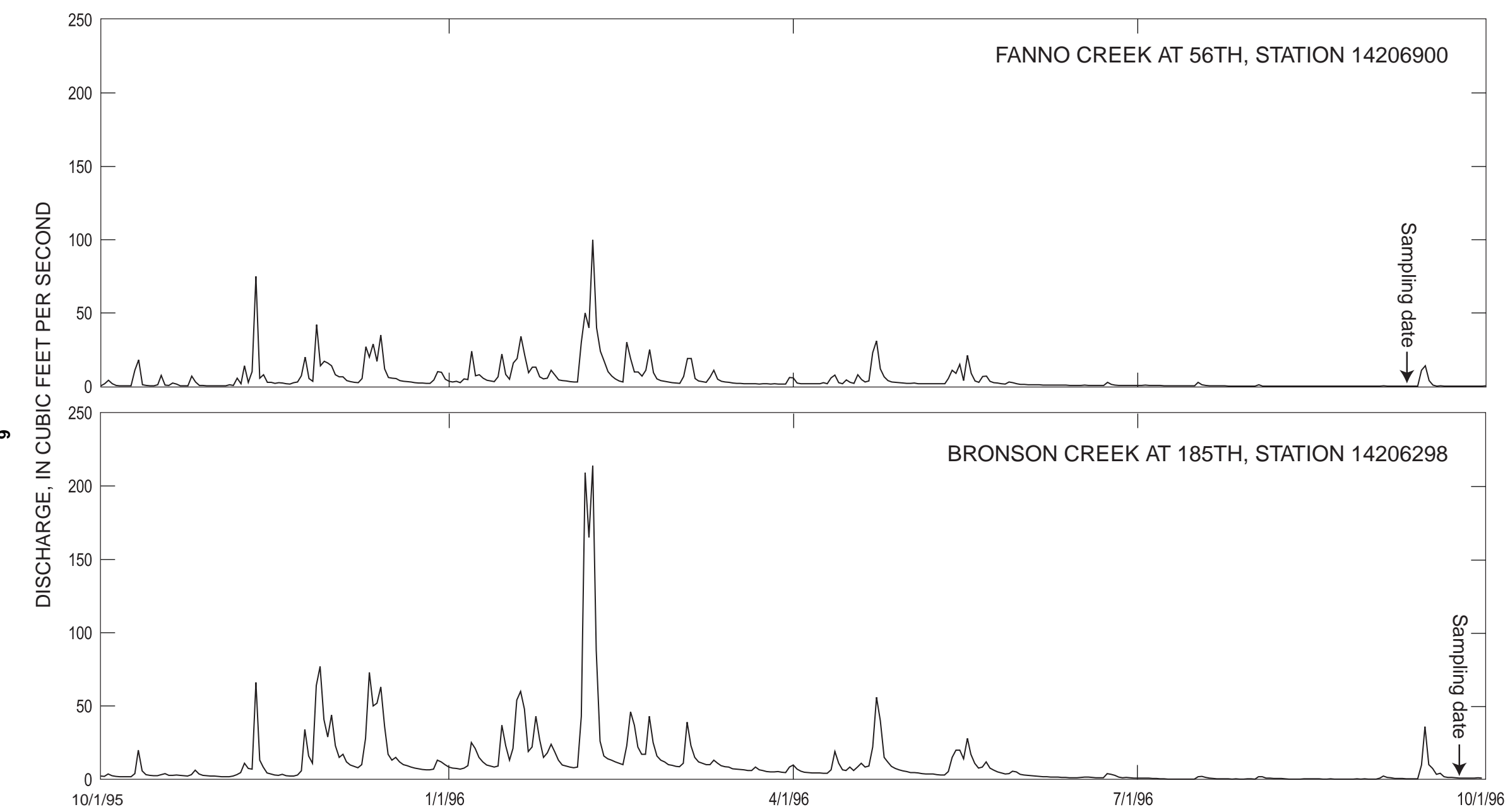

Figure 4. Fanno and Bronson Creeks, water year 1996. 


\section{DATA COLLECTION}

Water-quality and stream-discharge data representing base-flow conditions were collected at 19 main-stem and 22 tributary sites in the Fanno Creek subbasin on September 10 and 11, 1996. In the Bronson Creek subbasin, 14 main-stem and 4 tributary sites were sampled on September 24, 1996.

Water-quality sampling and analyses.Collection of water-quality samples was a joint effort by USA and USGS personnel. Water temperature, specific conductance, $\mathrm{pH}$, and dissolved oxygen were measured in the field using Hydrolab ${ }^{\mathrm{TM}}$ multiparameter water-quality sensors. Grab samples were collected and analyzed for major ions, trace elements, nutrients, and bacteria at the USA water-quality laboratory. Methods used for sample collection, processing, and analyses of chemical constituents; and for field and laboratory quality control are described by Doyle and Caldwell (1996). Bacterial samples were processed and analyzed using U.S. Environmental Protection Agency method 600/4-85-076.

Quality assurance and quality control.Duplicate samples were collected at two sites in the Fanno Creek subbasin and at one site in the Bronson Creek subbasin to help quantify the overall precision of the sampling and analytical methods. Results of duplicate analyses (presented with the regular data in the appendix) indicate acceptable precision.

Laboratory quality-control procedures included method blanks, travel blanks, spikes, and duplicate samples. The USA water-quality laboratory also participates in several performance-evaluation programs (e.g., the USGS Standard Reference Sample project, a monthly quality-assurance program run by the USGS Oregon District, an annual regional laboratory intercomparison study, and periodic reviews by the USGS Branch of Quality Systems) and has a record of highquality performance (Kelly et al., 1999; Rounds et al., 1999).

Streamflow measurements.-USGS personnel conducted instantaneous flow measurements at the time of water-quality sample collection (tables A1 and A4, appendix). Flow in small streams is inherently difficult to measure, and the accuracy of the data range from excellent to poor, depending on site-specific conditions. The best discharge measurements typically were made by collecting the entire flow into a container and measuring the volume collected over a specific period of time. Other streamflow measurements were performed using standard USGS techniques and calibrated type AA or pygmy flow meters (Buchanan and Somers, 1969). The largest errors were associated with very shallow stream reaches and rocky streambeds. The accuracy of each streamflow measurement is indicated in tables A1 and A4 (appendix).

\section{RESULTS}

Phosphorus and E. coli data collected during this study are presented and discussed in the following sections. Other data-such as major-ion concentrations-are presented in the appendix.

\section{Fanno Creek Subbasin}

Phosphorus.-Recent water-quality investigations have revealed that ground water is a major source of phosphorus to surface water throughout the Tualatin River Basin (Doyle and Caldwell, 1996; Tualatin Basin Technical Advisory Committee, 1997; Kelly et al., 1999; Wilson et al., 1999). Near the mouth of Fanno Creek, the background total phosphorus concentration attributable to ground-water base flow has been estimated to be approximately $0.14 \mathrm{mg} / \mathrm{L}$ by both the Tualatin Basin Technical Advisory Committee (TBTAC) and the Oregon Department of Environmental Quality (ODEQ) (http://waterquality.deq.state.or.us /wq/TMDLs/TMDLs.htm, accessed October 22, 1999). Piezometers installed in the Fanno Creek streambed as part of the ongoing USA-USGS investigation also show that local ground water contains substantial levels of phosphorus (table 1), and accompanying water-level and seepage measurements showed that this ground water was discharging to Fanno Creek.

Concentrations of total phosphorus at nearly $80 \%$ of sites measured in the Fanno Creek subbasin during the 1996 sampling were less than $0.2 \mathrm{mg} / \mathrm{L}$ (fig. 5), suggesting that ground-water base flow could account for most of the phosphorus present. Concentrations of total phosphorus throughout the subbasin also correlated positively with barium, iron, and aluminum ( $r>0.85)$, suggesting a common geological source of these constituents such as would be present in ground water. A few sites in the upper basin had total phosphorus concentrations less than $0.1 \mathrm{mg} / \mathrm{L}$ - possibly from a shallow, local groundwater system - and eight sites in the subbasin had concentrations greater than $0.2 \mathrm{mg} / \mathrm{L}$. However, concentrations at all sites measured along the lower 6 miles of Fanno Creek were near estimated background levels. These data suggest that during summer low-flow conditions in the Fanno Creek subbasin, no anthropogenic or other sources of phosphorus in addition to ground water are contributing significantly to phosphorus loads in the Tualatin River main stem. 
Table 1. Ground-water phosphorus data from piezometers installed in Fanno Creek

[Data-collection methods are described in Kelly et al. (1999)]

\begin{tabular}{cccccc}
\hline Location & River mile & $\begin{array}{c}\text { Depth of } \\
\text { screened interval } \\
\text { (feet below streambed) }\end{array}$ & Date sampled & $\begin{array}{c}\text { Total } \\
\text { phosphorus } \\
\text { (mg/L as P) }\end{array}$ \\
\hline Upstream of Hall Boulevard & 3.5 & 11.2 & $08-24-1995$ & 0.81 \\
Upstream of Hall Boulevard & 3.5 & 11.2 & $09-04-1996$ & .96 \\
Upstream of Hall Boulevard & 3.5 & 6.2 & $08-24-1995$ & .31 \\
Upstream of Hall Boulevard & 3.5 & 6.2 & $09-04-1996$ & .16 \\
Near Footbridge & .3 & 6.2 & $09-04-1996$ & .29 \\
\hline
\end{tabular}

At most sites on the Fanno Creek main stem, dissolved orthophosphate (fig. 6) accounted for $30-50 \%$ of the total phosphorus measured (fig. 7). Concentrations of dissolved orthophosphate varied most at tributary sites and in the upper reaches of the Fanno Creek main stem (fig. 6). Except for Vermont Creek, which had the highest level measured in the subbasin $(0.082 \mathrm{mg} / \mathrm{L})$, dissolved orthophosphate concentrations tended to be highest in the lower subbasin and were generally between 0.06 and $0.08 \mathrm{mg} / \mathrm{L}$ (as phosphorus) along the lower 9 miles of Fanno Creek. This pattern of dissolved orthophosphate can probably be attributed to ground-water base flow. In general, base flows in tributaries and in the upper reaches of Fanno Creek result from relatively shallow, local ground-water systems, while base flow in the lower reaches of Fanno Creek includes flow from the deeper, more regional system (Tualatin Basin Technical Advisory Committee, 1997). Ground water in shallow, local systems comes from small, localized recharge areas and follows short flow paths from recharge to discharge. As a result, the composition of shallow ground water can vary considerably even within a subbasin. In contrast, ground water in deeper, regional flow systems includes contributions from a more extensive recharge area and follows longer, deeper flow paths from recharge to discharge. As a result, the composition of regional ground water tends to vary little at the subbasin scale. In addition, the regional ground-water flow system in the Tualatin River Basin has been shown to contain higher concentrations of orthophosphate than local flow systems (Kelly et al., 1999; Wilson et al., 1999).

Pendleton Creek, a small tributary that enters Fanno Creek at river mile 12.2, had the highest total phosphorus concentration in the subbasin $(0.6 \mathrm{mg} / \mathrm{L})$, at approximately four times the estimated background concentration (fig. 5). In addition, dissolved orthophosphate accounted for only $5 \%$ of the total phosphorus measured in Pendleton Creek (fig. 7). The preponderance of particle-associated phosphorus suggests that a source other than ground-water base flow contributes phosphorus to Pendleton Creek. Several nearly stagnant ponds are present along the creek's flow path, and the decomposition of avian waste and other bottom sediments in these ponds may be the source of additional phosphorus. Biological and chemical processes in these ponds may also contribute to elevated levels of turbidity, total and suspended solids, ammonia, total Kjeldahl nitrogen, bacteria, barium, iron, and aluminum, which were high in Pendleton Creek relative to most other sites in the subbasin (tables A1-A3, appendix).

E. coli.-At approximately $70 \%$ of the sites sampled in the Fanno Creek subbasin, E. coli counts exceeded the current ODEQ single-sample criterion for recreational contact in freshwater-406 organisms/ $100 \mathrm{~mL}$ (fig. 8). Possible sources of E. coli to Fanno Creek include domestic pet and wildlife waste, failing septic systems, or improperly managed hobby farms. Furthermore, intensively developed areas tend to have elevated E. coli concentrations because of the increase in impervious surfaces associated with urban development. Washoff from such surfaces transfers microorganisms to streams more readily than runoff from undisturbed land. In contrast, $E$. coli levels measured during this same low-flow period in two nearby nonurbanized subbasins in the Tualatin River Basin (4 samples from Gales Creek and 5 samples from Dairy Creek; fig. 1) were less than the singlesample criterion (USA, unpub. data, 1996). 


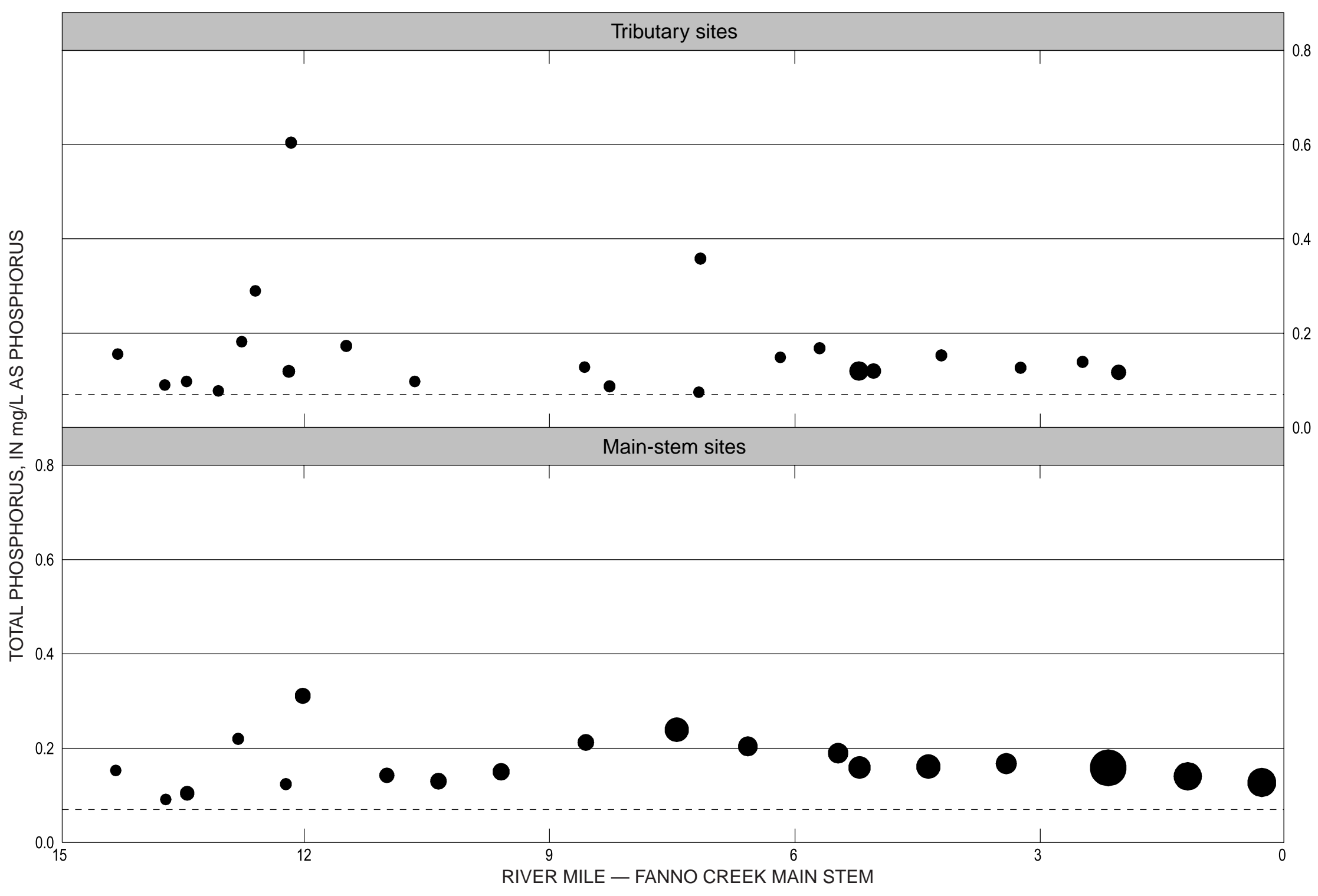

Figure 5. Total phosphorus in the Fanno Creek subbasin, September 1996. (Symbol diameters are proportional to the estimated instantaneous load, calculated as the product of discharge and concentration; dashed lines indicate Total Maximum Daily Load (TMDL) criterion of $0.07 \mathrm{mg}$ P/L [milligrams phosphorus per liter].) 


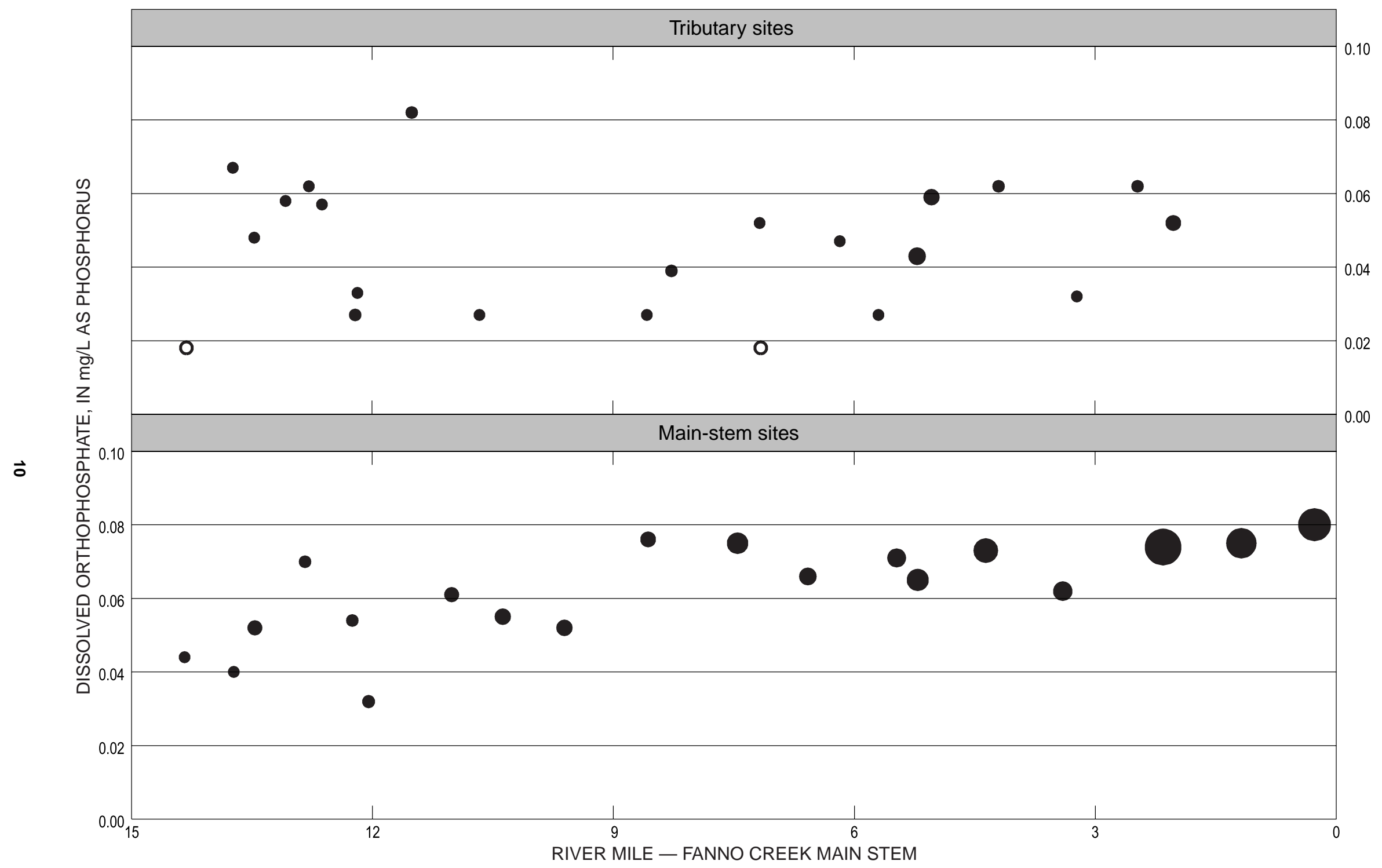

Figure 6. Dissolved orthophosphate in the Fanno Creek subbasin, September 1996. (Symbol diameters are proportional to the estimated instantaneous load, calculated as the product of discharge and concentration; solid symbols indicate measured concentration values; open symbols indicate estimated concentration values.) 


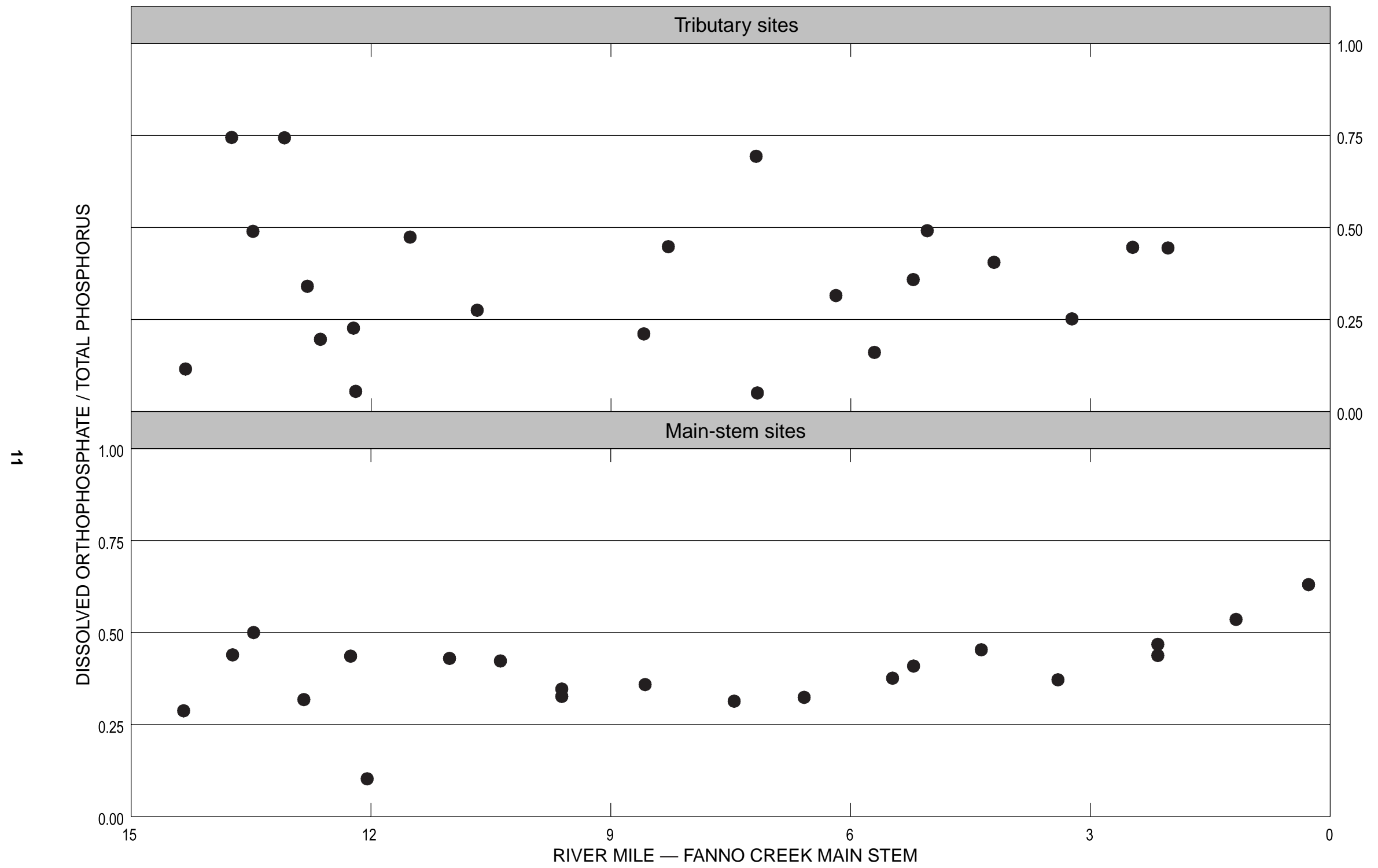

Figure 7. Ratio of dissolved orthophosphate to total phosphorus in the Fanno Creek subbasin, September 1996. 


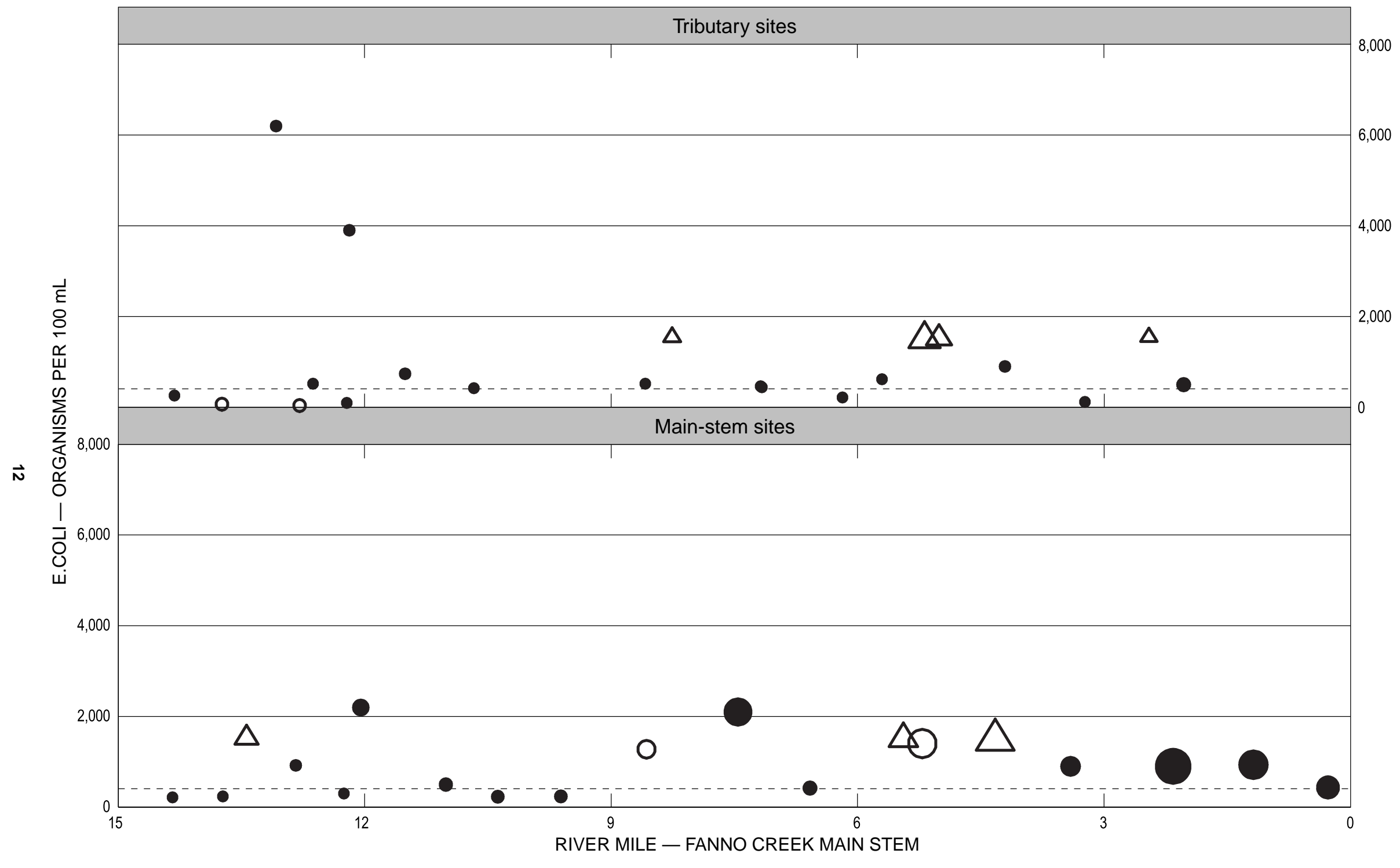

Figure 8. E. coli in the Fanno Creek subbasin, September 1996. (Symbol diameters are proportional to the estimated instantaneous load, calculated as the product of discharge and concentration; solid circles indicate measured concentration values; open circles indicate estimated concentration values; open triangles indicate actual concentration value is greater than the reported value; dashed lines indicate single-sample criterion of 406 organisms per $100 \mathrm{~mL}$ [milliliters] for recreational contact.) 
E. coli counts varied considerably in the upper subbasin. The highest counts in the subbasin were measured in the tributary near Shattuck Road (Fanno Creek river mile 13.1) and in Pendleton Creek (Fanno Creek river mile 12.2), but a number of sites in the upper subbasin met the single-sample criterion. The tributary near Shattuck Road also had elevated concentrations of chloride and total Kjeldahl nitrogen, suggesting input from a sewage source such as a failing septic system. Avian wastes deposited in ponds along Pendleton Creek may act as an E. coli source to that stream. E. coli concentrations were more consistent in the lower subbasin-every site sampled along the lower 9 miles of Fanno Creek exceeded the single-sample criterion.

\section{Bronson Creek Subbasin}

Phosphorus.-At all but one of the sites in the Bronson Creek subbasin, total phosphorus concentrations were between 0.1 and $0.2 \mathrm{mg} / \mathrm{L}$ (fig. 9).

Near the mouth of Rock Creek, the nearest stream to Bronson Creek for which a background total phosphorus concentration has been estimated, the background total phosphorus concentration was estimated by the TBTAC and the ODEQ as $0.22 \mathrm{mg} / \mathrm{L}$ (http://waterquality.deq.state.or.us/wq/TMDLs/ TMDLs.htm, accessed October 22, 1999). Bronson Creek is a tributary to Beaverton Creek, which in turn flows into Rock Creek. Ground water in the Bronson Creek subbasin is thus from a more localized flow system than ground water in the more downstream reaches of the Rock Creek subbasin, which probably accounts for the lower phosphorus concentrations in Bronson Creek. The phosphorus levels measured suggest that - with the exception of the most upstream site, Bronson Creek near Thompson Road (site B18)ground-water base flow from local ground-water systems in this subbasin can account for phosphorus concentrations in Bronson Creek during summer low-flow conditions. Additionally, the consistency in total phosphorus concentrations measured at all sites except B18 - including B12, the most upstream site on Bannister Creek, which drains an undeveloped and relatively pristine area-indicates that total phosphorus in this stream comes predominantly from a natural diffuse source, such as ground-water base flow, rather than anthropogenic point sources. The total phosphorus concentration measured at site B18 probably includes contributions from residential development in this part of the subbasin, but this influence was not apparent at any downstream sites. In contrast to previous studies (TBTAC, 1997), phosphorus concentrations remained fairly constant even as water passed through large instream ponds located along Bronson Creek between river miles 1.5 and 2.0.

Dissolved orthophosphate concentrations in the Bronson Creek subbasin were generally highest in the upper basin, except for the Thompson Road site (fig. 10). Ground-water base flow may account for this pattern of dissolved orthophosphate if the shallow, local ground-water system of the uppermost reaches of the Bronson Creek subbasin has higher dissolved orthophosphate concentrations than the relatively deeper ground water that feeds the lower reaches of Bronson Creek.

In addition to having the highest total phosphorus concentration in the subbasin, as well as the lowest ratio of dissolved orthophosphate to total phosphorus (fig. 11), Bronson Creek near Thompson Road (B18) had the highest measured values of turbidity, total and suspended solids, total Kjeldahl nitrogen, ammonia, $\mathrm{BOD}_{5}$, iron, barium, and aluminum (tables A4-A6, appendix). Many of these high values may be explained by the local influence of residential development and the low stream discharge at this site- the lowest discharge measured in the subbasin. Low flows have limited ability to dilute contaminants; therefore, even relatively small inputs of contaminants can have an appreciable impact on water quality in very small streams.

The highest dissolved orthophosphate concentrations and the lowest values for temperature, turbidity, specific conductance, dissolved and suspended solids, total phosphorus, and iron were measured in Bannister Creek, the only significant tributary of Bronson Creek (tables A4-A6, appendix). These data probably represent the composition of the shallow, local ground water contributing base flow to Bannister Creek.

E. coli.-E. coli counts at one-third of the sites sampled in the Bronson Creek subbasin exceeded the current ODEQ individual-sample criterion for recreational contact in freshwater-406 organisms/ $100 \mathrm{~mL}$ (fig. 12). Bacterial counts that exceeded the criterion were measured at the Thompson Road site, in the vicinity of Kaiser Road, at the West Union site, and at the most downstream site on Bannister Creek. In contrast, no E. coli levels exceeding the criterion were measured at any of the sites sampled along the lower 3 miles of Bronson Creek. As in the Fanno Creek subbasin, possible sources of E. coli to Bronson Creek include domestic pet and wildlife waste, failing septic systems, or improperly managed hobby farms. Generally lower E. coli levels in the Bronson Creek subbasin compared to those in the Fanno Creek subbasin can probably be largely attributed to less intensive urbanization. 


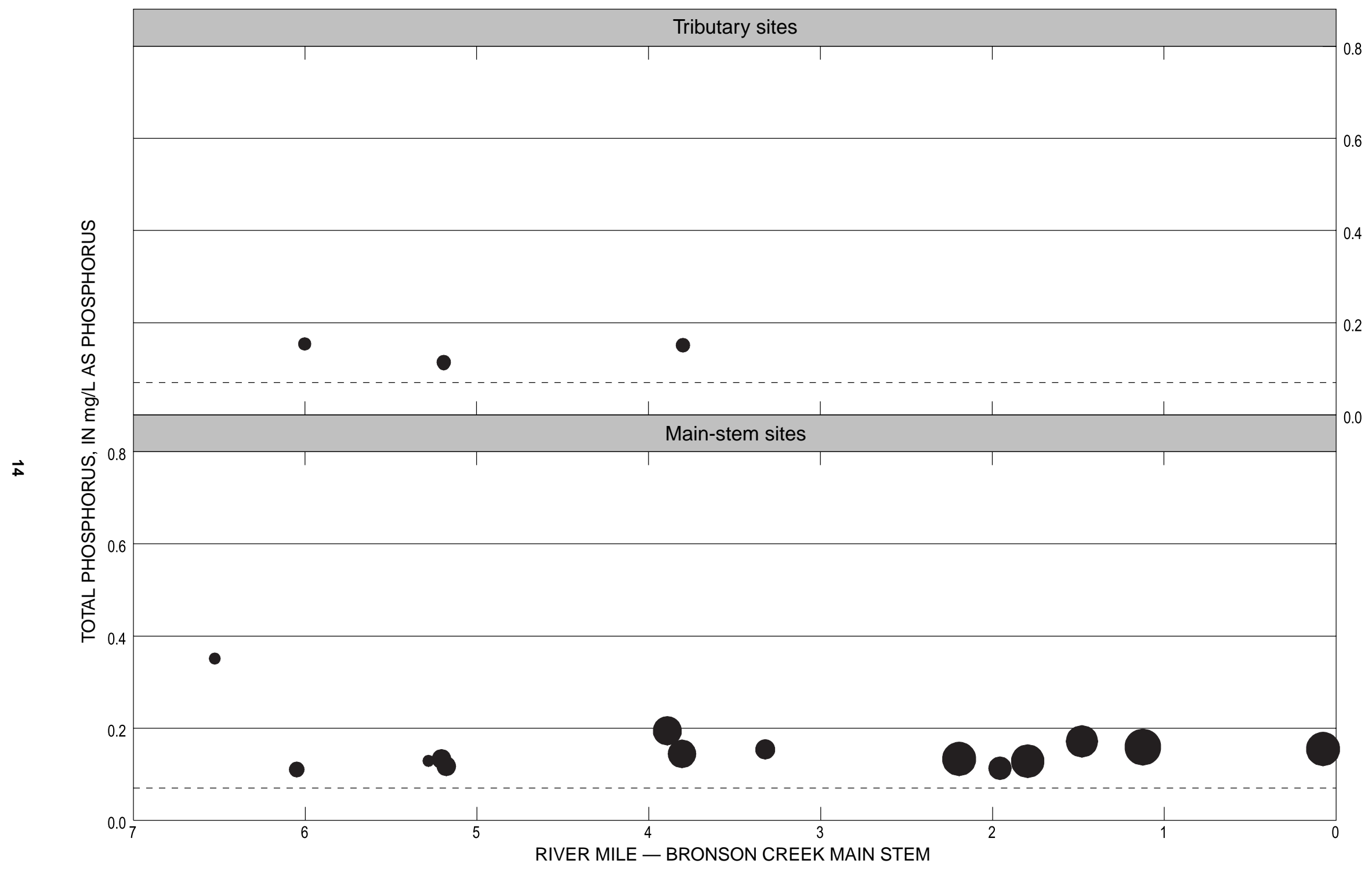

Figure 9. Total phosphorus in the Bronson Creek subbasin, September 1996. (Symbol diameters are proportional to the estimated instantaneous load, calculated as the product of discharge and concentration; dashed lines indicate Total Maximum Daily Load [TMDL] criterion of $0.07 \mathrm{mg}$ P/L [milligrams phosphorus per liter].) 


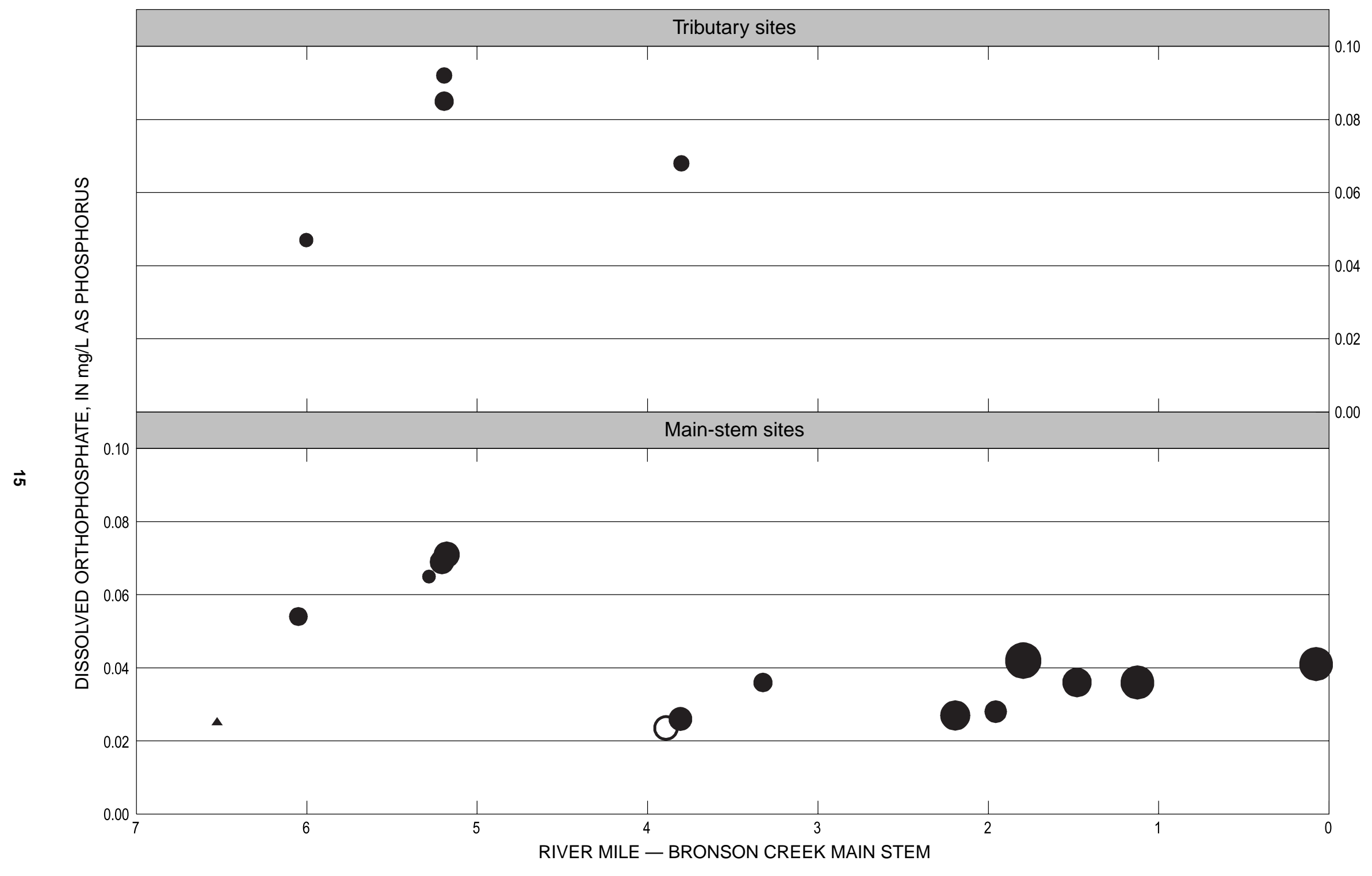

Figure 10. Dissolved orthophosphate in the Bronson Creek subbasin, September 1996. (Symbol diameters are proportional to the estimated instantaneous load, calculated as the product of discharge and concentration; solid symbols indicate measured concentration values; open symbols indicate estimated concentration values.) 


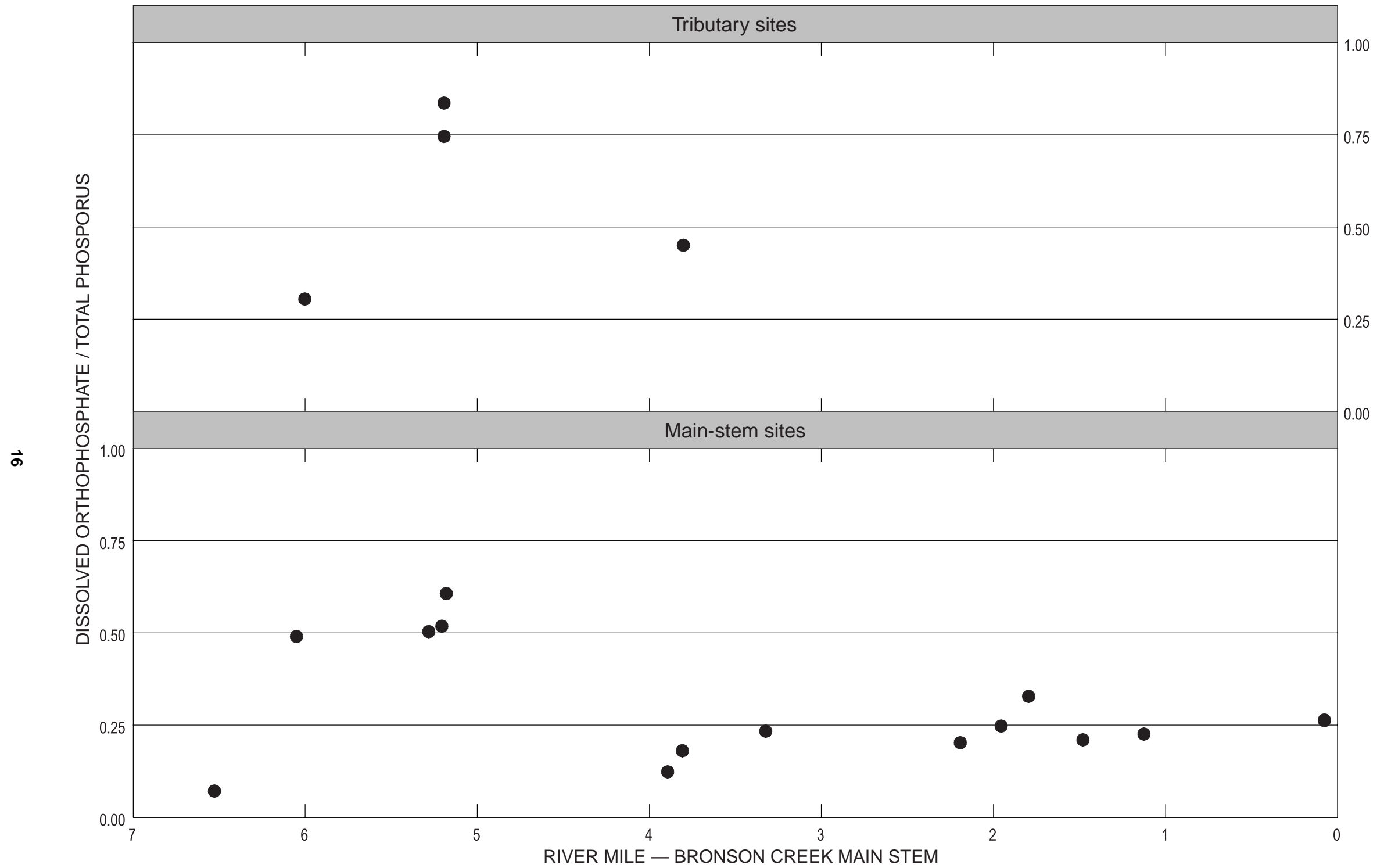

Figure 11. Ratio of dissolved orthophosphate to total phosphorus in the Bronson Creek subbasin, September 1996. 


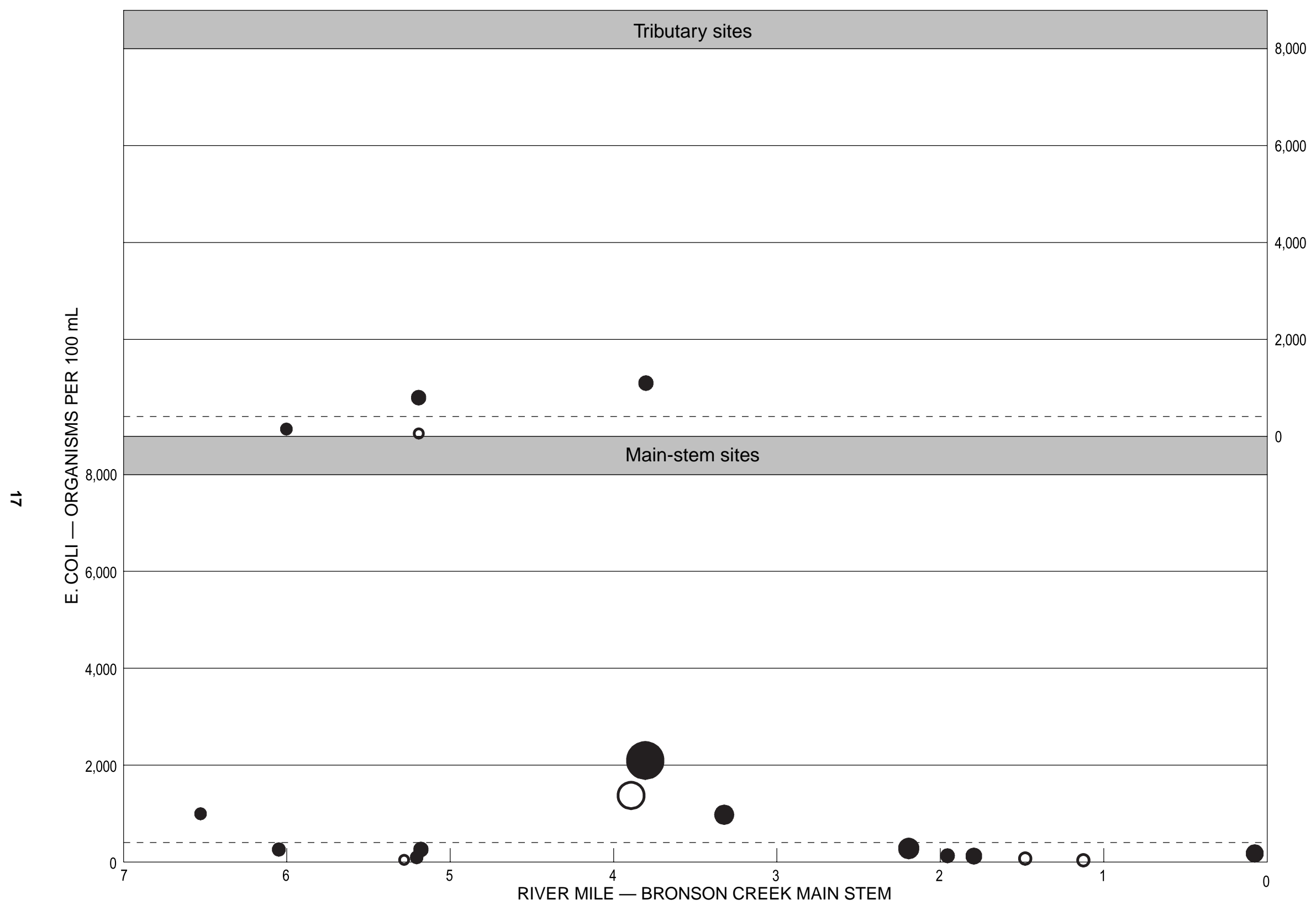

Figure 12. E. coli in the Bronson Creek subbasin, September 1996. (Symbol diameters are proportional to the estimated instantaneous load, calculated as the product of discharge and concentration; solid circles indicate measured concentration values; open circles indicate estimated concentration values; dashed lines indicate single-sample criterion of 406 organisms per $100 \mathrm{~mL}$ [milliliters] for recreational contact.) 


\section{SUMMARY}

As part of an ongoing investigation of waterquality conditions in the Tualatin River Basin, the Unified Sewerage Agency and the U.S. Geological Survey measured phosphorus and $E$. coli concentrations in the Fanno Creek and Bronson Creek subbasins. These measurements were made during September 1996 to characterize summer base-flow conditions in the two subbasins. Documenting phosphorus and E. coli concentrations and understanding their distribution during low-flow periods is important for developing effective subbasin water-management plans as well as understanding sources that contribute to loads in the Tualatin River main stem.

Phosphorus.-Studies of water quality in the Tualatin River Basin have shown that ground water in this region is rich in phosphorus. The Tualatin Basin Technical Advisory Committee and the Oregon Department of Environmental Quality have estimated background phosphorus concentrations for a number of subbasins based on ground-water and surface-water data from these studies (http://waterquality.deq.state. or.us/wq/TMDLs/TMDLs.htm, accessed October 22, 1999). Data from most of the sites sampled during the September 1996 study indicate that during summer low-flow conditions in the Fanno and Bronson Creek subbasins, total phosphorus concentrations were near estimated background values associated with groundwater base flow. Some upstream sites in each subbasin had phosphorus concentrations somewhat higher than could be attributed to a ground-water source, suggesting additional sources were contributing to instream phosphorus loads. However, the lower several miles of both Fanno and Bronson Creeks were near background, indicating that anthropogenic or other sources of phosphorus in addition to ground water were not contributing substantially to phosphorus loads to the Tualatin River main stem during this low-flow period.

Data collected during this study suggest that ponds associated with some of the tributaries in the Fanno Creek subbasin (e.g., Pendleton Creek and the tributary near Gemini) may be contributing to increased phosphorus levels, but in contrast to earlier studies (Tualatin Basin Technical Advisory Committee, 1997), phosphorus concentrations did not diminish as water passed through large instream ponds located along Bronson Creek between river miles 1.5 and 2.0. This illustrates that the effects of ponds on water quality can be transient.

E. coli.-Several sites in the Bronson Creek subbasin and most sites in the Fanno Creek subbasin exceeded the single-sample bacteria criterion for recreational contact in freshwater (406 organisms/ $100 \mathrm{~mL}$ ). Most of the elevated levels measured are typical of urbanized areas, and generally higher levels in the Fanno Creek subbasin can probably be attributed to greater urbanization there than in the Bronson Creek subbasin. For comparison, E. coli levels measured during this same low-flow period in two nonurbanized subbasins located just west of the study area (4 samples from Gales Creek and 5 samples from Dairy Creek; fig. 1) were less than the single-sample criterion (USA, unpub. data, 1996).

Within the Fanno Creek subbasin, particularly high E. coli levels in the vicinity of Shattuck Road and in Pendleton and Summer Creeks may indicate additional inputs from sources such as domestic pet and wildlife waste, failing septic systems, or improperly managed hobby farms. The tributary near Shattuck Road also had elevated concentrations of chloride and total Kjeldahl nitrogen, which is consistent with input from a sewage source such as a failing septic system. Avian wastes deposited in ponds along Pendleton Creek may also contribute E. coli to the stream.

E. coli data collected during this study show that at a few sites - the tributary near Shattuck Road and Pendleton Creek in the Fanno Creek subbasin and the area near Kaiser Road on Bronson Creek-E. coli levels were relatively high. However, there was no evidence in either subbasin of large-scale sources of bacterial contamination to surface water during the summer low-flow period investigated.

\section{REFERENCES}

Buchanan, T.J., and Somers, W.P., 1969, Discharge measurements at gaging stations: U.S. Geological Survey Techniques of Water-Resources Investigations, book 3, chap. A8, 65 p.

Doyle, M.C., and Caldwell, J.M., 1996, Water-quality, streamflow, and meteorological data for the Tualatin River Basin, Oregon, 1991-93: U. S. Geological Survey Open-File Report 96-173, 49 p. + CD-ROM.

Kelly, V.J., 1997, Dissolved oxygen in the Tualatin River, Oregon, during winter flow conditions, 1991 and 1992: U.S. Geological Survey Water-Supply Paper 2465-A, $68 \mathrm{p}$.

Kelly, V.J., Lynch, D.D., and Rounds, S.A., 1999, Sources and transport of phosphorus and nitrogen during lowflow conditions in the Tualatin River, Oregon, 1991-93: U.S. Geological Survey Water-Supply Paper 2465-C, 94 p.

Risley, J.C., 1997, Relations of Tualatin River water temperatures to natural and human-caused factors: U.S. Geological Survey Water-Resources Investigations Report 97-4071, 143 p. 
Rounds, S.A., Wood, T.M., and Lynch, D.D., 1999, Modeling discharge, temperature, and water quality in the Tualatin River, Oregon: U.S. Geological Survey Water-Supply Paper 2465-B, 121 p.

Tualatin Basin Technical Advisory Committee Nonpoint Source Subcommittee, 1997, Technical review of nonpoint sources of phosphorus and total maximum daily loads for tributaries in the Tualatin Basin, available from Oregon Department of Environmental Quality, Northwest Regional Office, Portland, Oregon, $146 \mathrm{p}$.

Wilson, D.C., Burns, S.F., Jarrell, Wesley, Lester, Alan, and Larson, Edwin, 1999, Natural ground-water discharge of orthophosphate in the Tualatin Basin, Northwest Oregon, Environmental and Engineering Geoscience, vol. V, no. 2, p. 189-197. 
Page Intentionally Blank 
APPENDIX 
Table A1. Discharge, phosphorus, nitrogen, and E. coli data collected in the Fanno Creek subbasin, September 10, 1996

[ $\mathrm{ft}^{3} / \mathrm{s}$, cubic feet per second; $\mathrm{mg} / \mathrm{L}$, milligrams per liter; $\mathrm{P}$, phosphorus; $\mathrm{NH}_{3}$, ammonia; $\mathrm{N}$, nitrogen; $\mathrm{mL}$, milliliters; number in brackets below parameter name indicates STORET (U.S. Environmental

Protection Agency Storage and Retrieval system database) code; Fanno Creek river mile is point of entry for tributaries; $\leq$, less than or equal to; A, error $\leq 2 \%$; B, error $\leq 5 \%$; C, error $\leq 8 \%$; D, error $>8 \%$; E, estimated value; --, no data; <, less than; >, greater than; bolded rows indicate main-stem sites and shaded rows indicate tributary sites]

\begin{tabular}{|c|c|c|c|c|c|c|c|c|c|c|c|}
\hline & $\begin{array}{c}\text { Fanno } \\
\text { Creek } \\
\text { river } \\
\text { mile }\end{array}$ & $\begin{array}{c}\text { Site } \\
\text { number }\end{array}$ & $\begin{array}{c}\text { Instantaneous } \\
\text { flow }\left(\mathrm{ft}^{3} / \mathbf{s}\right) \\
{[61]}\end{array}$ & $\begin{array}{c}\text { Quality } \\
\text { of flow } \\
\text { measurement }\end{array}$ & $\begin{array}{c}\text { Total } \\
\text { phosphorus } \\
\text { (mg/L as P) } \\
{[665]}\end{array}$ & $\begin{array}{c}\text { Dissolved } \\
\text { ortho- } \\
\text { phosphate } \\
\text { (mg/L as P) } \\
\text { [671] }\end{array}$ & $\begin{array}{c}\text { Ratio of } \\
\text { dissolved } \\
\text { ortho- } \\
\text { phosphate } \\
\text { to total } \\
\text { phosphorus }\end{array}$ & $\begin{array}{c}\text { Soluble } \\
\mathrm{NH}_{3} \\
\text { (mg/L as N) } \\
{[608]}\end{array}$ & $\begin{array}{c}\text { Total } \\
\text { Kjeldahl } \\
\text { nitrogen } \\
\text { (mg/L as N) } \\
\text { [625] }\end{array}$ & $\begin{array}{c}\text { Soluble } \\
\text { nitrate-nitrite } \\
\text { (mg/L as } \mathrm{N}) \\
\text { [631] }\end{array}$ & $\begin{array}{c}\text { E. coli } \\
\text { (organisms } \\
\text { per } 100 \mathrm{~mL} \text { ) } \\
{[31648]}\end{array}$ \\
\hline Fanno Creek at 30th & 14.3 & F41 & 0.007 & $\mathbf{C}$ & 0.15 & 0.044 & 0.29 & 0.064 & 0.58 & 1.1 & 220 \\
\hline Tributary at Dosch \& Highway 10 & 14.3 & $\mathrm{~F} 40$ & .004 & $\mathrm{C}$ & .16 & E.018 & E.11 & .11 & .48 & .33 & 260 \\
\hline Fanno Creek at 39th & 13.7 & F38 & .071 & $\mathbf{A}$ & .09 & .040 & .44 & $<.02$ & .86 & .62 & 240 \\
\hline Tributary at 38th \&39th Drive & 13.7 & F39 & .007 & A & .09 & .067 & .74 & $<.02$ & .26 & .30 & E 40 \\
\hline Ivey Creek at 45th & 13.5 & F37 & .004 & $\mathrm{C}$ & .10 & .048 & .49 & E.04 & .16 & .37 & 170 \\
\hline Fanno Creek at 45th & 13.5 & F36 & .8 & D & .10 & .052 & .50 & E.02 & .22 & .40 & $>1,600$ \\
\hline Tributary near Shattuck & 13.1 & $\mathrm{~F} 35$ & .008 & B & .08 & .058 & .74 & E.03 & 3.51 & .86 & 6,200 \\
\hline Fanno Creek at 56th & 12.8 & F34 & .082 & $\mathbf{C}$ & .22 & .070 & .32 & E .05 & 1.2 & .26 & 920 \\
\hline Taylor Creek near Seymour & 12.8 & F33 & .002 & A & .18 & .062 & .34 & .143 & .46 & .35 & E 8 \\
\hline Columbia Creek near mouth & 12.6 & F32 & .009 & $\mathrm{D}$ & .29 & .057 & .20 & E.03 & .68 & .72 & 520 \\
\hline Fanno Creek upstream of Sylvan Creek & 12.3 & F31 & .087 & $\mathbf{B}$ & .12 & .054 & .44 & E.02 & .42 & .20 & 300 \\
\hline Sylvan Creek & 12.2 & F30 & .23 & $\mathrm{D}$ & .12 & .027 & .23 & .07 & .45 & .18 & 96 \\
\hline Pendleton Creek & 12.2 & F29 & .023 & $\mathrm{C}$ & .60 & .033 & .05 & .445 & 1.77 & .38 & 3,900 \\
\hline Fanno Creek at Oleson & 12.0 & F28 & .41 & $\mathbf{C}$ & .31 & .032 & .10 & .15 & .89 & .21 & 2,200 \\
\hline Vermont Creek at Oleson & 11.5 & $\mathrm{~F} 27$ & .11 & $\mathrm{D}$ & .17 & .082 & .47 & .809 & 1.43 & 12.60 & 740 \\
\hline Fanno Creek at Nicole Road & 11.0 & F26 & .68 & $\mathbf{C}$ & .14 & .061 & .43 & E.04 & .46 & 1.1 & 500 \\
\hline Multnomah tributary at Oleson & 10.7 & $\mathrm{~F} 25$ & .06 & $\mathrm{D}$ & .10 & .027 & .28 & E.03 & .39 & .36 & 420 \\
\hline Fanno Creek at 86th & 10.4 & F24 & 1.0 & $\mathbf{C}$ & .13 & .055 & .42 & E .03 & .44 & .85 & 230 \\
\hline Fanno Creek near Allen & 9.6 & F23 & 1.1 & C & .15 & .052 & .35 & .11 & .73 & .85 & 240 \\
\hline Fanno Creek near Allen—DUPLICATE & 9.6 & $\mathbf{F} 23$ & -- & -- & .15 & .049 & .33 & .11 & .77 & .85 & 210 \\
\hline Wetland near Fanno Creek at Denny & 8.6 & $\mathrm{~F} 22$ & -- & -- & .13 & .027 & .21 & $<.02$ & .29 & $<.01$ & 520 \\
\hline Fanno Creek at Denny & 8.6 & F21 & 67 & $\mathbf{C}$ & .21 & .076 & .36 & .11 & .64 & .55 & E 1,300 \\
\hline
\end{tabular}


Table A1. Discharge, phosphorus, nitrogen, and E. coli data collected in the Fanno Creek subbasin, September 10, 1996-Continued

[ $\mathrm{ft}^{3} / \mathrm{s}$, cubic feet per second; $\mathrm{mg} / \mathrm{L}$, milligrams per liter; $\mathrm{P}$, phosphorus; $\mathrm{NH}_{3}$, ammonia; $\mathrm{N}$, nitrogen; $\mathrm{mL}$, milliliters; number in brackets below parameter name indicates STORET (U.S. Environmental

Protection Agency Storage and Retrieval system database) code; Fanno Creek river mile is point of entry for tributaries; $\leq$, less than or equal to; A, error $\leq 2 \%$; B, error $\leq 5 \%$; C, error $\leq 8 \%$; D, error $>8 \%$; E, estimated value; --, no data; <, less than; >, greater than; bolded rows indicate main-stem sites and shaded rows indicate tributary sites]

\begin{tabular}{|c|c|c|c|c|c|c|c|c|c|c|c|}
\hline & $\begin{array}{c}\text { Fanno } \\
\text { Creek } \\
\text { river } \\
\text { mile }\end{array}$ & $\begin{array}{c}\text { Site } \\
\text { number }\end{array}$ & $\begin{array}{c}\text { Instantaneous } \\
\text { flow }\left(\mathrm{ft}^{3} / \mathrm{s}\right) \\
{[61]}\end{array}$ & $\begin{array}{c}\text { Quality } \\
\text { of flow } \\
\text { measurement }\end{array}$ & $\begin{array}{c}\text { Total } \\
\text { phosphorus } \\
\text { (mg/L as P) } \\
{[665]}\end{array}$ & $\begin{array}{c}\text { Dissolved } \\
\text { ortho- } \\
\text { phosphate } \\
\text { (mg/L as P) } \\
\text { [671] }\end{array}$ & $\begin{array}{l}\text { Ratio of } \\
\text { dissolved } \\
\text { ortho- } \\
\text { phosphate } \\
\text { to total } \\
\text { phosphorus }\end{array}$ & $\begin{array}{c}\text { Soluble } \\
\mathrm{NH}_{3} \\
\text { (mg/L as } \mathrm{N}) \\
{[608]}\end{array}$ & $\begin{array}{c}\text { Total } \\
\text { Kjeldahl } \\
\text { nitrogen } \\
\text { (mg/L as N) } \\
{[625]}\end{array}$ & $\begin{array}{c}\text { Soluble } \\
\text { nitrate-nitrite } \\
\text { (mg/L as } \mathrm{N}) \\
\text { [631] }\end{array}$ & $\begin{array}{c}\text { E. coli } \\
\text { (organisms } \\
\text { per } 100 \mathrm{~mL} \text { ) } \\
{[31648]}\end{array}$ \\
\hline Tributary at Bel-Aire & 8.3 & $\mathrm{~F} 20$ & 0.16 & $\mathrm{C}$ & 0.09 & 0.039 & 0.45 & $<0.02$ & 0.25 & 0.29 & $>1,600$ \\
\hline Fanno Creek at Tuckerwood & 7.5 & F19 & 1.8 & $\mathbf{C}$ & .24 & .075 & .31 & E.04 & .55 & .39 & 2,100 \\
\hline Tributary at Greenway School & 7.2 & F18 & .04 & $\mathrm{D}$ & .08 & .052 & .69 & $<.02$ & .18 & .16 & 460 \\
\hline Tributary near Gemini & 7.2 & F17 & .05 & $\mathrm{C}$ & .36 & E.018 & E.05 & E.02 & 1.92 & .15 & 440 \\
\hline Fanno Creek at Scholls Ferry & 6.6 & F16 & 1.2 & B & .20 & .066 & .32 & .068 & .63 & .30 & 420 \\
\hline Tributary at Ironwood Loop & 6.2 & F15 & .038 & $\mathrm{~B}$ & .15 & .047 & .32 & E.03 & .45 & .51 & 220 \\
\hline Ash Creek at Greenburg & 5.7 & F14 & .07 & $\mathrm{C}$ & .17 & .027 & .16 & .053 & .59 & .03 & 620 \\
\hline Fanno Creek at Tigard Street & 5.5 & F13 & 1.4 & B & .19 & .071 & .38 & .075 & .64 & .32 & $>1,600$ \\
\hline Summer Creek at mouth (Tiedeman) & 5.2 & F12 & 1.8 & $\mathrm{D}$ & .12 & .043 & .36 & .062 & .47 & .45 & $>1,600$ \\
\hline Fanno Creek at Tiedeman & 5.2 & F11 & 2.3 & $\mathbf{C}$ & .16 & .065 & .41 & .062 & .55 & .38 & E 1,500 \\
\hline Tributary at Walnut & 5.0 & F10 & .9 & $\mathrm{D}$ & .12 & .059 & .49 & E.03 & .16 & 1.39 & $>1,600$ \\
\hline Fanno Creek at Main & 4.4 & F9 & 2.8 & $\mathbf{C}$ & .16 & .073 & .45 & .063 & .53 & .46 & $>1,600$ \\
\hline Tributary at A-boy (Main St. Apts.) & 4.2 & F8 & .099 & $\mathrm{C}$ & .15 & .062 & .41 & $<.02$ & .26 & .33 & 900 \\
\hline Fanno Creek at Hall & 3.4 & F7 & 2 & D & .17 & .062 & .37 & E.04 & .46 & .40 & 900 \\
\hline Red Rock at Hunziker & 3.2 & F6 & .1 & $\mathrm{D}$ & .13 & .032 & .25 & .056 & .52 & .06 & 120 \\
\hline Tributary at Fanno Creek Drive & 2.5 & F5 & .12 & A & .14 & .062 & .45 & E.04 & .27 & 1.87 & $>1,600$ \\
\hline Fanno Creek at Bonita & 2.2 & F4 & 7.1 & B & .16 & .074 & .47 & E.04 & .43 & .49 & 900 \\
\hline Fanno Creek at Bonita-DUPLICATE & 2.2 & F4 & -- & -- & .16 & .070 & .44 & E.04 & .45 & .48 & 860 \\
\hline Ball Creek at 74th & 2.0 & F3 & .91 & $\mathrm{C}$ & .12 & .052 & .44 & E.04 & .28 & .39 & 500 \\
\hline Fanno Creek at Durham Road & 1.2 & $\mathbf{F 2}$ & 4.5 & B & .14 & .075 & .54 & E.02 & .36 & .54 & 940 \\
\hline Fanno Creek at Footbridge & .3 & F1 & 5.3 & $\mathbf{C}$ & .13 & .080 & .63 & $<.02$ & .35 & .59 & 440 \\
\hline
\end{tabular}


Table A2. Field, oxygen-demand, and solids data collected in the Fanno Creek subbasin, September 10, 1996

$\left[\mathrm{C}\right.$, Celsius; $\mu \mathrm{S} / \mathrm{cm}$, microsiemens per centimeter at 25 degrees Celsius; $\mathrm{mg} / \mathrm{L}$, milligrams per liter; $\mathrm{CaCO}_{3}$, calcium carbonate; NTU, nephelometric turbidity units; number in brackets below parameter name indicates STORET (U.S. Environmental Protection Agency Storage and Retrieval system database) code; Fanno Creek river mile is point of entry for tributaries; <, less than; E, estimated value; --, no data; bolded rows indicate main-stem sites and shaded rows indicate tributary sites

\begin{tabular}{|c|c|c|c|c|c|c|c|c|c|c|c|c|c|}
\hline & $\begin{array}{c}\text { Fanno } \\
\text { Creek } \\
\text { river } \\
\text { mile }\end{array}$ & $\begin{array}{c}\text { Site } \\
\text { number }\end{array}$ & $\begin{array}{c}\text { Temperature } \\
\text { (degrees C) } \\
{[10]}\end{array}$ & $\begin{array}{c}\text { Field } \\
\mathrm{pH} \\
{[400]}\end{array}$ & $\begin{array}{c}\text { Field } \\
\text { conductivity } \\
(\mu \mathrm{S} / \mathrm{cm}) \\
{[94]}\end{array}$ & $\begin{array}{c}\text { Dissolved } \\
\text { oxygen } \\
(\mathrm{mg} / \mathrm{L}) \\
{[299]}\end{array}$ & $\begin{array}{c}\text { 5-day } \\
\text { biochemical } \\
\text { oxygen } \\
\text { demand } \\
(\mathrm{mg} / \mathrm{L}) \\
{[310]}\end{array}$ & $\begin{array}{c}\text { Total } \\
\text { chemical } \\
\text { oxygen } \\
\text { demand } \\
(\mathrm{mg} / \mathrm{L}) \\
{[340]}\end{array}$ & $\begin{array}{c}\text { Total } \\
\text { alkalinity } \\
(\mathrm{mg} / \mathrm{L} \text { as } \\
\left.\mathrm{CaCO}_{3}\right) \\
{[410]}\end{array}$ & $\begin{array}{c}\text { Total } \\
\text { solids } \\
(\mathrm{mg} / \mathrm{L}) \\
{[500]}\end{array}$ & $\begin{array}{c}\text { Total } \\
\text { dissolved } \\
\text { solids } \\
(\mathrm{mg} / \mathrm{L}) \\
{[515]}\end{array}$ & $\begin{array}{c}\text { Total } \\
\text { suspended } \\
\text { solids } \\
(\mathbf{m g} / \mathrm{L}) \\
{[530]}\end{array}$ & $\begin{array}{c}\text { Turbidity } \\
\text { (NTU) } \\
\text { [76] }\end{array}$ \\
\hline Fanno Creek at 30th & 14.3 & F41 & 16.1 & 7.6 & 160 & 9.4 & $<2$ & 14 & 79 & 180 & 150 & 29 & 10 \\
\hline Tributary at Dosch \& Highway 10 & 14.3 & F40 & 14.7 & 7.4 & 270 & 9.3 & $<2$ & 17 & 130 & 240 & 210 & 29 & 23 \\
\hline Fanno Creek at 39th & 13.7 & F38 & 14.4 & 7.5 & 200 & 9.0 & $<2$ & E 10 & 84 & 170 & 170 & 1.0 & 6.1 \\
\hline Tributary at 38th \&39th Drive & 13.7 & F39 & 14.3 & 7.7 & 200 & 8.6 & $<2$ & 12 & 89 & 180 & 170 & 4.0 & 2.8 \\
\hline Ivey Creek at 45 th & 13.5 & $\mathrm{~F} 37$ & 14.0 & 7.3 & 200 & 8.8 & $<2$ & E 10 & 86 & 170 & 160 & 5.6 & 4.6 \\
\hline Fanno Creek at 45th & 13.5 & F36 & 14.5 & 7.5 & 210 & 9.7 & $<2$ & E 8 & 93 & 180 & 170 & 3.6 & 7.0 \\
\hline Tributary near Shattuck & 13.1 & $\mathrm{~F} 35$ & 14.2 & 7.3 & 240 & 9.3 & $<2$ & 12 & 57 & 180 & 180 & .8 & 1.8 \\
\hline Fanno Creek at 56th & 12.8 & F34 & 13.9 & 7.3 & 210 & 6.3 & $>15$ & 34 & 92 & 180 & 180 & 6.0 & 10 \\
\hline Taylor Creek near Seymour & 12.8 & F33 & 20.6 & 7.4 & 200 & 9.9 & $<2$ & 12 & 80 & 160 & 150 & 6.4 & 6.9 \\
\hline Columbia Creek near mouth & 12.6 & $\mathrm{~F} 32$ & 13.2 & 7.5 & 190 & 9 & 2.1 & 26.1 & 72 & 270 & 160 & 100 & 40 \\
\hline Fanno Creek upstream of Sylvan Creek & 12.3 & F31 & 15.1 & 7.5 & 200 & 8.2 & $<2$ & 11 & 87 & 160 & 160 & 1.6 & 6.0 \\
\hline Sylvan Creek & 12.2 & $\mathrm{~F} 30$ & 16.6 & 7.3 & 190 & 7 & $<2$ & 20.2 & 75 & 160 & 150 & 6.6 & 15 \\
\hline Pendleton Creek & 12.2 & F29 & 20.6 & 7.4 & 260 & 8.5 & 3.4 & 35.5 & 120 & 470 & 240 & 230 & 96 \\
\hline Fanno Creek at Oleson & 12.0 & F28 & 13.2 & 7.4 & 200 & 6.5 & 2.1 & 28 & 86 & 260 & 170 & 91 & 56 \\
\hline Vermont Creek at Oleson & 11.5 & $\mathrm{~F} 27$ & 14.1 & 7.2 & 270 & 7.6 & 2.6 & 15 & 70 & 240 & 230 & 8.4 & 9 \\
\hline Fanno Creek at Nicole Road & 11.0 & F26 & 15.2 & 7.0 & 210 & 5.4 & $<2$ & 21 & 80 & 170 & 170 & 3.8 & 7.7 \\
\hline Multnomah tributary at Oleson & 10.7 & $\mathrm{~F} 25$ & 13.6 & 7.3 & 240 & 8.5 & $<2$ & 21.7 & 93 & 170 & 170 & 2.8 & 8.4 \\
\hline Fanno Creek at 86th & 10.4 & F24 & 14.4 & 7.3 & 210 & 7.0 & $<2$ & 21 & 81 & 160 & 160 & 3.0 & 5.1 \\
\hline Fanno Creek near Allen & 9.6 & F23 & 15.5 & 7.2 & 180 & 5.1 & $<2$ & 28 & 68 & 160 & 150 & 8.0 & 7.5 \\
\hline Fanno Creek near Allen-DUPLICATE & 9.6 & $\mathbf{F} 23$ & -- & -- & -- & -- & 2.3 & 28 & 67 & 150 & -- & 8.4 & -- \\
\hline Wetland near Fanno Creek at Denny & 8.6 & $\mathrm{~F} 22$ & -- & -- & -- & -- & $<2$ & E 10 & 45 & 140 & 84 & 53.8 & 12 \\
\hline Fanno Creek at Denny & 8.6 & F21 & 16.0 & 7.1 & 200 & 5.5 & $<2$ & 21 & 80 & 170 & 160 & 10 & 12 \\
\hline
\end{tabular}


Table A2. Field, oxygen-demand, and solids data collected in the Fanno Creek subbasin, September 10, 1996-Continued

$\left[\mathrm{C}\right.$, Celsius; $\mu \mathrm{S} / \mathrm{cm}$, microsiemens per centimeter at 25 degrees Celsius; $\mathrm{mg} / \mathrm{L}$, milligrams per liter; $\mathrm{CaCO}_{3}$, calcium carbonate; NTU, nephelometric turbidity units; number in brackets below parameter name indicates STORET (U.S. Environmental Protection Agency Storage and Retrieval system database) code; Fanno Creek river mile is point of entry for tributaries; <, less than; E, estimated value; --, no data; bolded rows indicate main-stem sites and shaded rows indicate tributary sites

\begin{tabular}{|c|c|c|c|c|c|c|c|c|c|c|c|c|c|}
\hline & $\begin{array}{c}\text { Fanno } \\
\text { Creek } \\
\text { river } \\
\text { mile }\end{array}$ & $\begin{array}{c}\text { Site } \\
\text { number }\end{array}$ & $\begin{array}{c}\text { Temperature } \\
\text { (degrees C) } \\
\text { [10] }\end{array}$ & $\begin{array}{c}\text { Field } \\
\mathrm{pH} \\
{[400]}\end{array}$ & $\begin{array}{c}\text { Field } \\
\text { conductivity } \\
(\mu \mathrm{S} / \mathrm{cm}) \\
{[94]}\end{array}$ & $\begin{array}{c}\text { Dissolved } \\
\text { oxygen } \\
(\mathrm{mg} / \mathrm{L}) \\
{[299]}\end{array}$ & $\begin{array}{c}\text { 5-day } \\
\text { biochemical } \\
\text { oxygen } \\
\text { demand } \\
\text { (mg/L) } \\
{[310]}\end{array}$ & $\begin{array}{c}\text { Total } \\
\text { chemical } \\
\text { oxygen } \\
\text { demand } \\
(\mathrm{mg} / \mathrm{L}) \\
{[340]}\end{array}$ & $\begin{array}{c}\text { Total } \\
\text { alkalinity } \\
\text { (mg/L as } \\
\left.\mathrm{CaCO}_{3}\right) \\
{[410]}\end{array}$ & $\begin{array}{c}\text { Total } \\
\text { solids } \\
(\mathrm{mg} / \mathrm{L}) \\
{[500]}\end{array}$ & $\begin{array}{c}\text { Total } \\
\text { dissolved } \\
\text { solids } \\
\text { (mg/L) } \\
{[515]}\end{array}$ & $\begin{array}{c}\text { Total } \\
\text { suspended } \\
\text { solids } \\
(\mathrm{mg} / \mathrm{L}) \\
{[530]}\end{array}$ & $\begin{array}{c}\text { Turbidity } \\
\text { (NTU) } \\
\text { [76] }\end{array}$ \\
\hline Tributary at Bel-Aire & 8.3 & $\mathrm{~F} 20$ & 16.6 & 7.4 & 190 & 8.8 & $<2$ & E 9 & 76 & 150 & 150 & 3.6 & 5.5 \\
\hline Fanno Creek at Tuckerwood & 7.5 & F19 & 17.0 & 7.1 & 200 & 6.3 & $<2$ & 25 & 79 & 170 & 150 & 13 & 13 \\
\hline Tributary at Greenway School & 7.2 & F18 & 16.2 & 7.6 & 240 & 7.3 & $<2$ & E 9 & 110 & 180 & 180 & 2.4 & 2.5 \\
\hline Tributary near Gemini & 7.2 & F17 & 17.4 & 6.7 & 610 & $<1$ & 2.2 & 51.7 & 92 & 330 & 310 & 23 & 20 \\
\hline Fanno Creek at Scholls Ferry & 6.6 & F16 & 16.8 & 7.1 & 250 & 4.5 & $<2$ & 22 & 88 & 190 & 180 & 8.2 & 10 \\
\hline Tributary at Ironwood Loop & 6.2 & F15 & 16.2 & 6.8 & 260 & 3.6 & $<2$ & 24.9 & 120 & 210 & 210 & 5.2 & 8.7 \\
\hline Ash Creek at Greenburg & 5.7 & F14 & 18.5 & 7 & 330 & 2.4 & $<2$ & 25.9 & 130 & 230 & 230 & 6.4 & 7.1 \\
\hline Fanno Creek at Tigard Street & 5.5 & F13 & 17.6 & 7.2 & 260 & 5.7 & $<2$ & 23 & 92 & 190 & 180 & 9.2 & 10 \\
\hline Summer Creek at mouth (Tiedeman) & 5.2 & $\mathrm{~F} 12$ & 18.7 & 7.4 & 270 & 7.2 & $<2$ & 13 & 110 & 210 & 200 & 9.8 & 8.2 \\
\hline Fanno Creek at Tiedeman & 5.2 & F11 & 17.6 & 7.4 & 260 & 7.2 & $<2$ & 18 & 97 & 200 & 190 & 10 & 9.8 \\
\hline Tributary at Walnut & 5.0 & F10 & 15.4 & 7.5 & 230 & 8.8 & $<2$ & E 6 & 96 & 180 & 180 & 2.4 & 5.9 \\
\hline Fanno Creek at Main & 4.4 & F9 & $\mathbf{1 7 . 6}$ & 7.5 & 260 & 7.2 & $<2$ & 18 & 100 & 190 & 190 & 7.6 & 8.5 \\
\hline Tributary at A-boy (Main St. Apts.) & 4.2 & F8 & 15.3 & 7.6 & 250 & 8.5 & $<2$ & E 7 & 120 & 220 & 210 & 14.2 & 4.6 \\
\hline Fanno Creek at Hall & 3.4 & F7 & 18.3 & 7.6 & 260 & 7.3 & $<2$ & 15 & 110 & 210 & 200 & 11 & 9.2 \\
\hline Red Rock at Hunziker & 3.2 & F6 & 17.2 & 7.1 & 220 & 3.6 & $<2$ & 20.8 & 95 & 180 & 160 & 17.6 & 11 \\
\hline Tributary at Fanno Creek Drive & 2.5 & F5 & 15.0 & 7.6 & 250 & 8.7 & $<2$ & E 6 & 110 & 220 & 220 & 5.4 & 8 \\
\hline Fanno Creek at Bonita & 2.2 & $\mathbf{F 4}$ & 17.2 & 7.2 & 250 & 5.8 & $<2$ & 17 & 100 & 190 & 190 & 5.8 & 6.0 \\
\hline Fanno Creek at Bonita-DUPLICATE & 2.2 & F4 & -- & -- & -- & -- & $<2$ & 16 & 100 & 200 & -- & 5.6 & -- \\
\hline Ball Creek at 74 th & 2.0 & F3 & 16.4 & 7.4 & 230 & 8.3 & $<2$ & E 7 & 91 & 170 & 160 & 4 & 5.5 \\
\hline Fanno Creek at Durham Road & 1.2 & $\mathbf{F 2}$ & 17.2 & 7.3 & 240 & 7.3 & $<2$ & 13 & 98 & 180 & 180 & 2.0 & 4.2 \\
\hline Fanno Creek at Footbridge & .3 & F1 & 17.2 & 7.6 & 240 & 7.9 & $<2$ & 13 & 98 & 190 & 180 & 2.4 & 3.5 \\
\hline
\end{tabular}


Table A3. Major-ion data collected in the Fanno Creek subbasin, September 10, 1996

$[\mathrm{mg} / \mathrm{L}$, milligrams per liter; $\mu \mathrm{g} / \mathrm{L}$, micrograms per liter; number in brackets below parameter name indicates STORET (U.S. Environmental Protection Agency Storage and Retrieval system database) code; Fanno Creek river mile is point of entry for tributaries; E, estimated value; bolded rows indicate main-stem sites and shaded rows indicate tributary sites]

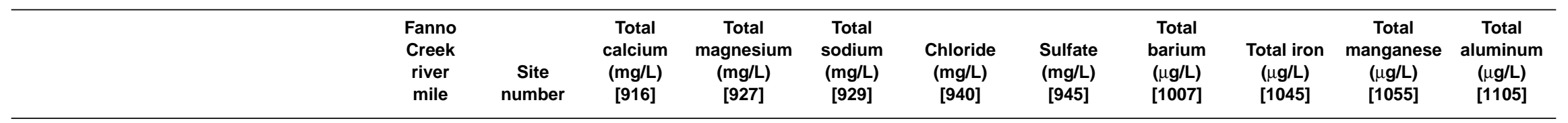

\begin{tabular}{|c|c|c|c|c|c|c|c|c|c|c|c|}
\hline Fanno Creek at 30th & 14.3 & F41 & 25 & 7.5 & 11 & 7.3 & 9.0 & 35 & 2,200 & 320 & 1,000 \\
\hline Tributary at Dosch \& Highway 10 & 14.3 & $\mathrm{~F} 40$ & 35 & 11 & 13 & 6.7 & 5.8 & 47 & 4,500 & 1,000 & 1,500 \\
\hline Fanno Creek at 39th & 13.7 & F38 & 25 & 8.0 & 10 & 8.3 & 6.5 & 29 & 1,100 & 130 & E 100 \\
\hline Tributary at 38th \& 39th Drive & 13.7 & F39 & 26 & 8.3 & 10 & 6.7 & 9.5 & 37 & 450 & 51 & E 200 \\
\hline Ivey Creek at 45 th & 13.5 & F37 & 23 & 7.9 & 10 & 6.7 & 6.9 & 31 & 1,200 & 380 & E 200 \\
\hline Fanno Creek at 45th & 13.5 & F36 & 25 & 8.7 & 10 & 6.1 & 5.7 & 31 & 1,100 & 240 & E 300 \\
\hline Tributary near Shattuck & 13.1 & F35 & 23 & 6.3 & 17 & 29.0 & 10.9 & 48 & 300 & 16 & E 100 \\
\hline Fanno Creek at 56th & 12.8 & F34 & 25 & 8.3 & 11 & 9.6 & 5.7 & 36 & 1,400 & 360 & E 300 \\
\hline Taylor Creek near Seymour & 12.8 & F33 & 24 & 6.0 & 11 & 10.6 & 6.7 & 36 & 1,700 & 1,400 & E 200 \\
\hline Columbia Creek near mouth & 12.6 & F32 & 23 & 7.4 & 13 & 13.3 & 8.6 & 83 & 6,500 & 380 & 6,300 \\
\hline Fanno Creek upstream of Sylvan Creek & 12.3 & F31 & 24 & 7.8 & 10 & 7.5 & 6.7 & 33 & 1,000 & 140 & E 100 \\
\hline Sylvan Creek & 12.2 & $\mathrm{~F} 30$ & 22 & 7.3 & 9 & 8.3 & 10.0 & 38 & 2,200 & 450 & 810 \\
\hline Pendleton Creek & 12.2 & F29 & 32 & 12.8 & 14 & 9.5 & 6.7 & 170 & 16,400 & 1,200 & 16,000 \\
\hline Fanno Creek at Oleson & 12.0 & F28 & 25 & 8.7 & 11 & 8.4 & 8.9 & 92 & 8,000 & 860 & 6,900 \\
\hline Vermont Creek at Oleson & 11.5 & F27 & 28 & 10.2 & 12 & 8.2 & 6.7 & 46 & 1,400 & 86 & 550 \\
\hline Fanno Creek at Nicole Road & 11.0 & F26 & 24 & 7.8 & 10 & 8.4 & 9.1 & 39 & 1,300 & 230 & 420 \\
\hline Multnomah tributary at Oleson & 10.7 & F25 & 28 & 8.6 & 10 & 6.7 & 13.3 & 39 & 1,300 & 160 & E 300 \\
\hline Fanno Creek at 86th & 10.4 & F24 & 24 & 7.7 & 10 & 8.5 & 9.4 & 33 & 840 & 150 & E 200 \\
\hline Fanno Creek near Allen & 9.6 & F23 & 21 & 6.7 & 8.3 & 7.3 & 8.6 & 37 & 1,300 & 340 & 520 \\
\hline Fanno Creek near Allen-DUPLICATE & 9.6 & $\mathbf{F} 23$ & 21 & 6.6 & 8.2 & 7.6 & 8.2 & 38 & 1,300 & 340 & 520 \\
\hline Wetland near Fanno Creek at Denny & 8.6 & F22 & 12 & 3.5 & 13 & 4.6 & 9.3 & 34 & 2,600 & 170 & 2,000 \\
\hline Fanno Creek at Denny & 8.6 & F21 & 23 & 7.6 & 10 & 8.0 & 8.1 & 43 & $\mathbf{1 , 8 0 0}$ & 550 & 890 \\
\hline
\end{tabular}


Table A3. Major-ion data collected in the Fanno Creek subbasin, September 10, 1996-Continued

$[\mathrm{mg} / \mathrm{L}$, milligrams per liter; $\mu \mathrm{g} / \mathrm{L}$, micrograms per liter; number in brackets below parameter name indicates STORET (U.S. Environmental Protection Agency Storage and Retrieval system database) code; Fanno Creek river mile is point of entry for tributaries; E, estimated value; bolded rows indicate main-stem sites and shaded rows indicate tributary sites]

\begin{tabular}{|c|c|c|c|c|c|c|c|c|c|c|c|}
\hline & $\begin{array}{l}\text { Fanno } \\
\text { Creek } \\
\text { river } \\
\text { mile }\end{array}$ & $\begin{array}{c}\text { Site } \\
\text { number }\end{array}$ & $\begin{array}{c}\begin{array}{c}\text { Total } \\
\text { calcium } \\
(\mathrm{mg} / \mathrm{L})\end{array} \\
{[916]}\end{array}$ & $\begin{array}{c}\text { Total } \\
\text { magnesium } \\
(\mathrm{mg} / \mathrm{L}) \\
{[927]}\end{array}$ & $\begin{array}{c}\begin{array}{c}\text { Total } \\
\text { sodium }\end{array} \\
\text { (mg/L) } \\
{[929]}\end{array}$ & $\begin{array}{c}\text { Chloride } \\
\text { (mg/L) } \\
{[940]}\end{array}$ & $\begin{array}{c}\text { Sulfate } \\
(\mathrm{mg} / \mathrm{L}) \\
{[945]}\end{array}$ & $\begin{array}{c}\begin{array}{c}\text { Total } \\
\text { barium } \\
(\mu \mathrm{g} / \mathrm{L}) \\
{[1007]}\end{array} \\
{[100}\end{array}$ & $\begin{array}{c}\text { Total iron } \\
(\mu \mathrm{g} / \mathrm{L}) \\
{[1045]}\end{array}$ & $\begin{array}{c}\text { Total } \\
\text { manganese } \\
(\mu \mathrm{g} / \mathrm{L}) \\
{[1055]}\end{array}$ & $\begin{array}{c}\text { Total } \\
\text { aluminum } \\
(\mu \mathrm{g} / \mathrm{L}) \\
{[1105]}\end{array}$ \\
\hline Tributary at Bel-Aire & 8.3 & $\mathrm{~F} 20$ & 21 & 6.4 & 12 & 6.6 & 10.7 & 36 & 1,600 & 160 & E 300 \\
\hline Fanno Creek at Tuckerwood & 7.5 & F19 & 23 & 7.5 & 11 & 8.2 & 8.5 & 43 & 2,000 & 360 & 1,200 \\
\hline Tributary at Greenway School & 7.2 & F18 & 32 & 9.8 & 13 & 5.4 & 8.5 & 29 & 330 & 36 & E 200 \\
\hline Tributary near Gemini & 7.2 & F17 & 41 & 10.2 & 34 & 78.5 & 9.4 & 67 & 3,800 & 630 & 490 \\
\hline Fanno Creek at Scholls Ferry & 6.6 & F16 & 30 & 8.5 & 15 & 19 & 8.7 & 45 & 1,500 & 450 & 630 \\
\hline Tributary at Ironwood Loop & 6.2 & F15 & 33 & 11.2 & 11 & 5.8 & 9.0 & 56 & 1,300 & 810 & 520 \\
\hline Ash Creek at Greenburg & 5.7 & F14 & 36 & 13.6 & 14 & 24.1 & E 3 & 38 & 1,200 & 1,200 & E 200 \\
\hline Fanno Creek at Tigard Street & 5.5 & F13 & 29 & 9.2 & 15 & 20 & 8.0 & 45 & 1,500 & 390 & 860 \\
\hline Summer Creek at mouth (Tiedeman) & 5.2 & F12 & 33 & 11.6 & 14 & 16.0 & 8.4 & 53 & 1,200 & 310 & 830 \\
\hline Fanno Creek at Tiedeman & 5.2 & F11 & 31 & 10 & 14 & 17 & 8.9 & 49 & $\mathbf{1 , 5 0 0}$ & 330 & 990 \\
\hline Tributary at Walnut & 5.0 & F10 & 27 & 9.9 & 10 & 7.4 & 7.2 & 27 & 1,000 & 170 & E 200 \\
\hline Fanno Creek at Main & 4.4 & F9 & 32 & 10 & 13 & 16 & 9.1 & 47 & 1,200 & 310 & 660 \\
\hline Tributary at A-boy (Main St. Apts.) & 4.2 & $\mathrm{~F} 8$ & 35 & 11.6 & 10 & 6.5 & 8.8 & 39 & 1,400 & 550 & 540 \\
\hline Fanno Creek at Hall & 3.4 & F7 & 33 & 11 & 13 & 15 & 8.9 & 49 & 1,400 & 420 & 750 \\
\hline Red Rock at Hunziker & 3.2 & F6 & 31 & 8.9 & 11 & 11.0 & 5.3 & 66 & 2,000 & 1,200 & 1,300 \\
\hline Tributary at Fanno Creek Drive & 2.5 & F5 & 33 & 12.2 & 10 & 6.5 & 11.0 & 30 & 1,400 & 340 & E 300 \\
\hline Fanno Creek at Bonita & 2.2 & F4 & 30 & 11 & 12 & 13 & 8.8 & 40 & 1,200 & 290 & E 400 \\
\hline Fanno Creek at Bonita-DUPLICATE & 2.2 & F4 & 29 & 11 & 12 & 13 & 8.5 & 38 & 940 & 290 & E 400 \\
\hline Ball Creek at 74th & 2.0 & F3 & 28 & 9.9 & 10 & 6.1 & 9.6 & 32 & 1,100 & 190 & E 300 \\
\hline Fanno Creek at Durham Road & 1.2 & F2 & 31 & 11 & 12 & 11 & 9.4 & 38 & 800 & 230 & E 200 \\
\hline Fanno Creek at Footbridge & .3 & F1 & 30 & 9.9 & 12 & 12 & 8.7 & 36 & 580 & 160 & E 100 \\
\hline
\end{tabular}


Page Intentionally Blank 
Table A4. Discharge, phosphorus, nitrogen, and E. coli data collected in the Bronson Creek subbasin, September 24, 1996

$\left[\mathrm{ft}^{3} / \mathrm{s}\right.$, cubic feet per second; $\mathrm{mg} / \mathrm{L}$, milligrams per liter; $\mathrm{NH}_{3}$, ammonia; $\mathrm{mL}$, milliliters; number in brackets below parameter name indicates STORET (U.S. Environmental Protection Agency Storage and Retrieval system database) code; Bronson Creek river mile is point of entry for tributaries; $\leq$, less than or equal to; A, error $\leq 2 \%$; B, error $\leq 5 \%$; C, error $\leq 8 \%$; D, error $>8 \%$; E, estimated value; --, no data; $<$, less than; bolded rows indicate main-stem sites and shaded rows indicate tributary sites]

\begin{tabular}{|c|c|c|c|c|c|c|c|c|c|c|c|}
\hline & $\begin{array}{c}\text { Bronson } \\
\text { Creek } \\
\text { river } \\
\text { mile }\end{array}$ & $\begin{array}{c}\text { I } \\
\text { Site } \\
\text { number }\end{array}$ & $\begin{array}{c}\text { Instantaneous } \\
\text { flow } \\
\left(\mathrm{ft}^{3} / \mathrm{s}\right) \\
{[61]}\end{array}$ & $\begin{array}{c}\text { Quality } \\
\text { of flow } \\
\text { measure- } \\
\text { ment }\end{array}$ & $\begin{array}{c}\text { Total } \\
\text { phosphorus } \\
\text { (mg/L as P) } \\
{[665]}\end{array}$ & $\begin{array}{c}\text { Dissolved } \\
\text { ortho- } \\
\text { phosphate } \\
\text { (mg/L as P) } \\
\text { [671] }\end{array}$ & $\begin{array}{c}\text { Ratio of } \\
\text { dissolved } \\
\text { ortho- } \\
\text { phosphate } \\
\text { to total } \\
\text { phosphorus }\end{array}$ & $\begin{array}{c}\text { Soluble } \\
\mathrm{NH}_{3} \\
\text { (mg/L as N) } \\
{[608]}\end{array}$ & $\begin{array}{c}\text { Total } \\
\text { Kjeldahl } \\
\text { nitrogen } \\
\text { (mg/L as N) } \\
\text { [625] }\end{array}$ & $\begin{array}{c}\text { Soluble } \\
\text { nitrate-nitrite } \\
\text { (mg/L as N) } \\
\text { [631] }\end{array}$ & $\begin{array}{c}\text { E. coli } \\
\text { (organisms } \\
\text { per } 100 \mathrm{~mL} \text { ) } \\
{[31648]}\end{array}$ \\
\hline Bronson Creek near Thompson Road & 6.5 & B18 & 0.006 & $\mathbf{A}$ & 0.35 & E 0.025 & E 0.07 & 0.52 & 1.8 & 0.47 & 1,000 \\
\hline South Bronson Creek near Laidlaw & 6.0 & B17 & .12 & $\mathbf{B}$ & .11 & .054 & .49 & $<.02$ & .20 & .63 & 260 \\
\hline North Bronson Creek near Laidlaw & 6.0 & B16 & .041 & A & .15 & .047 & .31 & E.05 & .27 & .13 & 150 \\
\hline Bronson Creek at Saltzman Road & 5.3 & B15 & .02 & D & .13 & .065 & .50 & E.02 & .18 & .63 & E 10 \\
\hline Bronson Creek upstream of Bannister & 5.2 & B14 & .19 & $\mathbf{C}$ & .13 & .069 & .52 & $<.02$ & .21 & .61 & 96 \\
\hline Bannister at Laidlaw & 5.2 & B13 & .082 & $\mathrm{C}$ & .11 & .085 & .75 & $<.02$ & .14 & .17 & 800 \\
\hline Bannister at 124th & 5.2 & B12 & .038 & A & .11 & .092 & .84 & $<.02$ & E.1 & .40 & E 20 \\
\hline Bronson Creek downstream of Bannister & 5.2 & B11 & .22 & $\mathbf{C}$ & .12 & .071 & .61 & $<.02$ & .22 & .52 & 260 \\
\hline Bronson Creek upstream of Kaiser Road & 3.9 & B10 & .38 & $\mathbf{C}$ & .19 & E .024 & E.13 & E .03 & .34 & .56 & E 1,000 \\
\hline Bronson Creek at Kaiser Road & 3.8 & B9 & .49 & $\mathbf{C}$ & .14 & .026 & .18 & E .03 & .33 & .54 & 2,100 \\
\hline Tributary downstream of Kaiser Road & 3.8 & B8 & .056 & $\mathrm{C}$ & .15 & .068 & .45 & E.03 & .45 & 2.6 & 1,100 \\
\hline Bronson Creek at West Union & 3.3 & B7 & .20 & $\mathbf{C}$ & .15 & .036 & .23 & $<.02$ & .35 & .78 & 980 \\
\hline Bronson Creek at Bronson Creek Park & 2.2 & B6 & .8 & D & .13 & .027 & .20 & $<.02$ & .38 & .18 & 280 \\
\hline Bronson Creek at Cornell & 2.0 & B5 & .4 & D & .11 & .028 & .25 & $<.02$ & .32 & .099 & 130 \\
\hline Bronson Creek at 179th & 1.8 & B4 & .8 & D & .13 & .042 & .33 & E .03 & .45 & E .03 & 120 \\
\hline Bronson Creek at 185th & 1.5 & B3 & .6 & D & .17 & .036 & .21 & $<.02$ & .87 & E.03 & E 60 \\
\hline Bronson Creek at Walker Road & 1.1 & B2 & .79 & $\mathbf{C}$ & .16 & .036 & .23 & $<.02$ & .67 & .10 & E 60 \\
\hline Bronson Creek near 205th & .1 & B1 & .7 & D & .16 & .041 & .26 & E .03 & .45 & .14 & 180 \\
\hline Bronson Creek near 205th-DUPLICATE & .1 & B1 & -- & -- & .16 & .042 & .26 & E .03 & .46 & .13 & 140 \\
\hline
\end{tabular}


Table A5. Field, oxygen-demand, and solids data collected in the Bronson Creek subbasin, September 24, 1996

$\left[\mathrm{C}\right.$, Celsius; $\mu \mathrm{S} / \mathrm{cm}$, microsiemens per centimeter at 25 degrees Celsius; $\mathrm{mg} / \mathrm{L}$, milligrams per liter; $\mathrm{CaCO}_{3}$, calcium carbonate; NTU, nephelometric turbidity units; number in brackets below parameter name indicates STORET (U.S. Environmental Protection Agency Storage and Retrieval system database) code; Bronson Creek river mile is point of entry for tributaries; <, less than; E, estimated value; --, no data; bolded rows indicate main-stem sites and shaded rows indicate tributary sites

\begin{tabular}{|c|c|c|c|c|c|c|c|c|c|c|c|c|}
\hline $\begin{array}{l}\text { Bronson } \\
\text { Creek } \\
\text { river } \\
\text { mile }\end{array}$ & $\begin{array}{c}\text { Site } \\
\text { number }\end{array}$ & $\begin{array}{l}\text { Ire } \\
\text { C) }\end{array}$ & $\begin{array}{c}\text { Field } \\
\mathrm{pH} \\
{[400]}\end{array}$ & $\begin{array}{c}\text { Field } \\
\text { conductivity } \\
(\mu \mathrm{S} / \mathrm{cm}) \\
{[94]}\end{array}$ & $\begin{array}{c}\text { Dissolved } \\
\text { oxygen } \\
\text { (mg/L) } \\
{[299]}\end{array}$ & $\begin{array}{c}\text { 5-day } \\
\text { biochemical } \\
\text { oxygen } \\
\text { demand } \\
\text { (mg/L) } \\
{[310]}\end{array}$ & $\begin{array}{c}\text { Total } \\
\text { chemical } \\
\text { oxygen } \\
\text { demand } \\
\text { (mg/L) } \\
{[340]}\end{array}$ & $\begin{array}{c}\text { Total } \\
\text { alkalinity } \\
\text { (mg/L as } \\
\mathrm{CaCO}_{3} \text { ) } \\
{[410]}\end{array}$ & $\begin{array}{c}\text { Total } \\
\text { solids } \\
\text { (mg/L) } \\
{[500]}\end{array}$ & $\begin{array}{c}\text { Total } \\
\text { dissolved } \\
\text { solids } \\
\text { (mg/L) } \\
{[515]}\end{array}$ & $\begin{array}{c}\text { Total } \\
\text { suspended } \\
\text { solids } \\
\text { (mg/L) } \\
{[530]}\end{array}$ & $\begin{array}{c}\text { Turbid- } \\
\text { ity } \\
\text { (NTU) } \\
{[76]}\end{array}$ \\
\hline
\end{tabular}

\begin{tabular}{|c|c|c|c|c|c|c|c|c|c|c|c|c|c|}
\hline Bronson Creek near Thompson Road & 6.5 & B18 & 11.0 & 7.6 & 200 & 9.3 & 3.9 & 24 & 57 & 210 & 150 & 61 & 48 \\
\hline South Bronson Creek near Laidlaw & 6.0 & B17 & 9.9 & 8.2 & 160 & 12 & $<2$ & E 7 & 52 & 140 & 130 & 5.6 & 12 \\
\hline North Bronson Creek near Laidlaw & 6.0 & B16 & 10.5 & 8.1 & 180 & 12 & $<2$ & 40 & 73 & 170 & 150 & 24 & 17 \\
\hline Bronson Creek at Saltzman Road & 5.3 & B15 & 10.5 & 8.1 & 210 & 12 & $<2$ & E 7 & 67 & 160 & 150 & 4.4 & 9.2 \\
\hline Bronson Creek upstream of Bannister & 5.2 & B14 & 9.9 & 7.6 & 200 & 9.8 & $<2$ & E 6 & 64 & 150 & 150 & 3.0 & 9.3 \\
\hline Bannister at Laidlaw & 5.2 & B13 & 9.6 & 7.4 & 180 & 9.4 & $<2$ & E 6 & 66.8 & 150 & 150 & 2 & 3.8 \\
\hline Bannister at 124th & 5.2 & B12 & 10.4 & 7.7 & 160 & 10.9 & $<2$ & $<5$ & 56.8 & 140 & 130 & 3.6 & 4.9 \\
\hline Bronson Creek downstream of Bannister & 5.2 & B11 & 9.8 & 7.5 & 200 & 10 & $<2$ & E 7 & 65 & 150 & 150 & 3.0 & 8.2 \\
\hline Bronson Creek upstream of Kaiser Road & 3.9 & B10 & 10.2 & 7.2 & 240 & 7.1 & $<2$ & 13 & 77 & 190 & 180 & 8.2 & 18 \\
\hline Bronson Creek at Kaiser Road & 3.8 & B9 & 10.5 & 7.2 & 260 & 7.1 & $<2$ & 11 & 80 & 190 & 180 & 10 & 19 \\
\hline Tributary downstream of Kaiser Road & 3.8 & B8 & 11.9 & 7.2 & 210 & 7.8 & $<2$ & E 6 & 59 & 170 & 150 & 20 & 11 \\
\hline Bronson Creek at West Union & 3.3 & B7 & 11.3 & 7.3 & 250 & 8.5 & $<2$ & 11 & 76 & 190 & 180 & 11 & 21 \\
\hline Bronson Creek at Bronson Creek Park & 2.2 & B6 & 10.6 & 7.6 & 260 & 9.0 & $<2$ & 15 & 86 & 170 & 170 & 3.2 & 10 \\
\hline Bronson Creek at Cornell & 2.0 & B5 & 13.2 & 7.5 & 230 & 11 & $<2$ & 13 & 85 & 170 & 160 & 4.0 & 8.0 \\
\hline Bronson Creek at 179th & 1.8 & B4 & 12.8 & 7.7 & 230 & 6.4 & $<2$ & 16 & 86 & 170 & 160 & 2.6 & 6.1 \\
\hline Bronson Creek at 185th & 1.5 & $\mathbf{B 3}$ & 14.8 & 7.6 & 190 & 8.7 & 2.6 & 26 & 67 & 160 & 140 & 12 & 12 \\
\hline Bronson Creek at Walker Road & 1.1 & B2 & 13.4 & 7.3 & 200 & 7.2 & $<2$ & 23 & 73 & 160 & 150 & 9.2 & 12 \\
\hline Bronson Creek near 205th & .1 & B1 & 12.0 & 7.1 & 200 & 7.5 & $<2$ & 17 & 76 & 160 & 150 & 5.2 & 12 \\
\hline Bronson Creek near 205th-DUPLICATE & .1 & B1 & -- & -- & -- & -- & $<2$ & 18 & 75 & 160 & -- & 5.2 & -- \\
\hline
\end{tabular}


Table A6. Major-ion data collected in the Bronson Creek subbasin, September 24, 1996

$[\mathrm{mg} / \mathrm{L}$, milligrams per liter; $\mu \mathrm{g} / \mathrm{L}$, micrograms per liter; number in brackets below parameter name indicates STORET (U.S. Environmental Protection Agency Storage and Retrieval system database) code; Bronson Creek river mile is point of entry for tributaries; <, less than; E, estimated value; bolded rows indicate main-stem sites and shaded rows indicate tributary sites]

\begin{tabular}{|c|c|c|c|c|c|c|c|c|c|c|c|}
\hline & $\begin{array}{c}\text { Bronson } \\
\text { Creek } \\
\text { river } \\
\text { mile }\end{array}$ & $\begin{array}{c}\text { Site } \\
\text { number }\end{array}$ & $\begin{array}{c}\text { Total } \\
\text { calcium } \\
(\mathrm{mg} / \mathrm{L}) \\
{[916]}\end{array}$ & $\begin{array}{c}\text { Total } \\
\text { magnesium } \\
(\mathrm{mg} / \mathrm{L}) \\
{[927]}\end{array}$ & $\begin{array}{c}\begin{array}{c}\text { Total } \\
\text { sodium } \\
(\mathrm{mg} / \mathrm{L})\end{array} \\
{[929]}\end{array}$ & $\begin{array}{c}\text { Chloride } \\
\text { (mg/L) } \\
{[940]}\end{array}$ & $\begin{array}{c}\text { Sulfate } \\
\text { (mg/L) } \\
{[945]}\end{array}$ & $\begin{array}{c}\begin{array}{c}\text { Total } \\
\text { barium } \\
(\mu \mathrm{g} / \mathrm{L})\end{array} \\
{[1007]}\end{array}$ & $\begin{array}{c}\text { Total } \\
\text { iron } \\
(\mu \mathrm{g} / \mathrm{L}) \\
{[1045]}\end{array}$ & $\begin{array}{c}\text { Total } \\
\text { manganese } \\
(\mu \mathrm{g} / \mathrm{L}) \\
{[1055]}\end{array}$ & $\begin{array}{c}\text { Total } \\
\text { aluminum } \\
(\mu \mathrm{g} / \mathrm{L}) \\
{[1105]}\end{array}$ \\
\hline Bronson Creek near Thompson Road & 6.5 & B18 & 20 & 6 & 12 & 8 & 7 & 83 & 6,200 & 430 & 6,000 \\
\hline South Bronson Creek near Laidlaw & 6.0 & B17 & 16 & 5.4 & 10 & 5.1 & 5.2 & 30 & 1,700 & 110 & 1,300 \\
\hline North Bronson Creek near Laidlaw & 6.0 & B16 & 21 & 7.5 & 8.1 & 4.0 & $<2.5$ & 44 & 3,300 & 240 & 2,100 \\
\hline Bronson Creek at Saltzman Road & 5.3 & B15 & 21 & 7.2 & 13 & 10 & 4.3 & 36 & 1,400 & 46 & 910 \\
\hline Bronson Creek upstream of Bannister & 5.2 & B14 & 23 & 6.8 & 13 & 8.8 & 5.0 & 38 & 1,400 & 82 & 800 \\
\hline Bannister at Laidlaw & 5.2 & B13 & 20 & 7.1 & 10 & 9.8 & $<2.5$ & 36 & 680 & 43 & E 400 \\
\hline Bannister at 124 th & 5.2 & B12 & 17 & 5.8 & 8.1 & 4.1 & $<2.5$ & 29 & 560 & E 8 & 660 \\
\hline Bronson Creek downstream of Bannister & 5.2 & B11 & 22 & 6.8 & 12 & 9.6 & E 4 & 37 & 1,200 & 72 & 730 \\
\hline Bronson Creek upstream of Kaiser Road & 3.9 & B10 & 29 & 8.5 & 14 & 18 & 5.4 & 47 & 2,500 & 740 & 1,300 \\
\hline Bronson Creek at Kaiser Road & 3.8 & B9 & 30 & 8.9 & 14 & 18 & E 4 & 47 & 2,600 & 690 & $\mathbf{1 , 5 0 0}$ \\
\hline Tributary downstream of Kaiser Road & 3.8 & B8 & 22 & 6.2 & 13 & 9.2 & 10 & 49 & 1,400 & 120 & 1,300 \\
\hline Bronson Creek at West Union & 3.3 & B7 & 29 & 8.9 & 14 & 17 & E 5 & 48 & 2,500 & 320 & 1,900 \\
\hline Bronson Creek at Bronson Creek Park & 2.2 & B6 & 27 & 8.8 & 13 & 15 & E 4 & 29 & 1,600 & 320 & E 300 \\
\hline Bronson Creek at Cornell & 2.0 & B5 & 31 & 9.1 & 13 & 15 & E 3 & 28 & 1,300 & 140 & E 300 \\
\hline Bronson Creek at 179th & 1.8 & B4 & 31 & 9.0 & 12 & 13 & 7.7 & 27 & 910 & 57 & E 300 \\
\hline Bronson Creek at 185th & 1.5 & B3 & 25 & 7.1 & 9.7 & 11 & 6.5 & 29 & 1,400 & 110 & 980 \\
\hline Bronson Creek at Walker Road & 1.1 & B2 & 26 & 7.6 & 9.8 & 11 & 6.6 & 35 & 1,500 & 130 & 1,100 \\
\hline Bronson Creek near 205th & .1 & B1 & 29 & 7.9 & 9.6 & 10 & 8.7 & 38 & 1,700 & 350 & 780 \\
\hline Bronson Creek near 205th-DUPLICATE & .1 & B1 & 29 & 8.0 & 9.4 & 10 & 8.4 & 39 & 1,700 & 350 & 800 \\
\hline
\end{tabular}


Page Intentionally Blank 